\title{
Neotropical felid specimens at the Museu Paraense Emilio Goeldi: species, distribution, and morphometric data
}

\author{
Alexandra Maria Ramos Bezerra ${ }^{1,2}$ \& Samanta Uchôa Bordallo ${ }^{1,3}$ \\ 1 Museu Paraense "Emílio Goeldi" (MPEG), Coleção de Mastozoologia (COZO0). Belém, PA, Brasil. \\ 2 ORCID: 0000-0002-7972-5535. E-mail: amrbezerra@hotmail.com \\ 3 ORCID: 0000-0001-7752-8223. E-mail: bordallo@gmail.com. Programa de Bolsas IC/FAPESPA.
}

\begin{abstract}
Museu Paraense Emilio Goeldi (MPEG), situated at Brazilian state of Pará, houses the third largest South-American mammal scientific collection, being a primary source of information for the study of Amazonian and Neotropical mammalians. The collection holds 245 felid specimens, comprising 210 skulls, 53 skins, 10 skeletons, and two anatomical pieces, representing $90 \%$ of wild Brazilian cat species, mainly from localities of Northern Brazil. We presented a list of this material, indexed by the genera and species. We also provided craniodental measurements of all the specimens with skull, and comment on the conservation status of the species and other remarkable data, including the first record of Leopardus tigrinus in the Brazilian state of Rondônia.
\end{abstract}

Key-Words. Herpailurus; Leopardus; Panthera, Puma; Scientific collection.

\section{INTRODUCTION}

The mammal collection in the Brazilian museum Museu Paraense Emilio Goeldi (MPEG) is the third largest collection of this kind in South America (Bezerra, 2013), and is one of the main source of information for mammalian Amazonian diversity. This collection includes about 45,000 specimens, among stuffed and opened skins, skulls, postcranium skeletons, and whole body fluid preserved, and 45 nomenclatural types (Silva Jr., MPEG curator, pers. comm. in December 2017). The current MPEG's mammal collection was firstly gathered by Swiss zoologist Emilio Goeldi in late XIX century (Goeldi \& Hagmann, 1906; Sanjad, 2006), and until 1955 was discontinuously managed and improved, when the ornithologist Fernando da Costa Novaes taken responsibility for the Zoology Division (Silva et al., 2005). Aiming to trainee undergraduate students in taxonomy and mammal scientific collection routines, areas on which few move towards in several regions of Brazil, and organize and redeem information about the MPEG's mammal collection, it was developed a large project focusing on all these themes. Here, we present one of the results of this of this project, a report of Neotropical felid specimens at the MPEG's mammal collection.

The family Felidae has worldwide distribution, except in the Poles, and in the Neotropical region can be found between 12 to 19 species belonged to four genera, Herpailurus Severtzov, 1858, Leopardus Gray, 1842, Puma Jardine, 1834, and Panthera Oken, 1916 (Nascimento, 2010; Kitchener et al., 2017). This variation in species number is due mainly to recent taxonomic revisions of the genus Leopardus (Nascimento, 2010, 2014; Nascimento \& Feijó, 2017), which have revalidated some species (Kitchener et al., 2017). Almost all species of felids are included in some threatened category from national and international lists, and several species groups need taxonomic revision (Kitchener et al., 2017).

Here, we presented an account of the wild Neotropical felids species at MPEG, including number of specimens, geographical distribution and representation, data on the sex, preservation type, and measurement of external and craniodental characters. We also comment on conservation status and other remarkable data, such as the comparison with the felid specimens reported for the mammal collection of MPEG in early $20^{\text {th }}$ century (Goeldi \& Hagmann, 1906). This is a product directly related to the project "Roedores do estado do Pará: padrões de distribuição e diversidade e o papel das coleções biológicas", started in 2016 on the organizing and divulgation of mammalian collection of the Museu Paraense Emilio Goeldi.

\section{MATERIAL AND METHODS}

\section{Specimen identification and distribution}

The nomenclature follows Kichener et al. (2017) for Felidae, and Nascimento $(2010,2014)$ 
and Nascimento \& Feijó (2017) for the genus Leopardus. Geographic distribution and assessment of the morphological characters follow those authors and Sunquist \& Sunquist (2009). Threatened status classification follows the Brazilian Official List of Endangered Species (DOU, 2014) and the IUCN Red List (IUCN, 2017), categories Vulnerable $=$ VU, Endangered $=E N$, Critically Endangered $=\mathrm{CR}$. Also were considered the Convention on International Trade in Endangered Species of Wild Fauna and Fauna (CITES) Appendices I = threatened with extinction risk, II = not necessarily now threatened with extinction but that may become so unless trade is closely controlled or species whose species in trade look like those listed for conservations reasons, and III = a list of species included at the request of a Party that already regulates trade in the species and that needs the cooperation of other countries to prevent unsustainable or illegal exploitation (CITES, 2017).

Data on locality, collector, collection date, sex, external and craniodental measurements, preparation type, and any other kind of information (e.g., if skull and/or skin is damaged, if was taken sample for genetic analysis) were included in a spreadsheet Excel ${ }^{\circledR}$ and show in the Results section.

For coordinates were utilized the software Google Earth Pro (Google Inc., 2018) and the database from 'IBGE cidades' (IBGE, 2018), federal conservation unities under management of 'Instituto Chico Mendes de Conservação da Biodiversidade' (ICMBio, 2018), and "Terras Indígenas" (FUNAI, 2018). Maps were generated in QGIS version 2.18.9 'Las Palmas' (QGIS, 2017), using map shapes from IBGE (1992) for Brazilian ecological tension areas and from USGS (2017) for South American ecosystems.

Specimens with only federative unity of Brazil or with large extension area as locality were no figured in the maps (e.g., Mato Grosso state, lower Amazon River, and Marajó Archipelago). Specimens from Parque Zoobotânico do Museu Emilio Goeldi, Belém, Pará state, Brazil, not received geographic coordinates.

\section{Biometry}

External measurements made in flesh were taken from original labels and are as follow: Body size length $(\mathrm{HBL})$, tail length $(\mathrm{T})$, inside ear length $(E)$, hind foot without claws (HF) are given in millimeters ( $\mathrm{mm}$ ), and weight (W) in grams (g). All specimens with skull were measured. Twenty-nine craniodental quantitative characters follow Nascimento (2010) and Nascimento \& Feijó (2017) and were taken using with a digital calliper (Mitutoyo ${ }^{\circledR}$ ): GLS = greatest length of the skull, from anteriormost premaxilla to occipital ridge; $\mathrm{CBL}=$ condylobasal length, from anterior face of upper incisors to intern face of anterior edge of occipital condyle; $\mathrm{RL}=$ rostral length, from anteriormost premaxilla to suture with the maxilla; $L R L=$ lateral rostral length, from nasal lateral end to infraorbital foramen; NL = nasal length; $N B=$ nasal breadth, measured between the lateral ends; NSL = nasal suture length, between nasal bones; $I O B=$ interorbital length, at maxilla-premaxilla suture; PPB = postorbital processes breadth, cranial breadth between postorbital processes; $\mathrm{POB}=$ postorbital breadth, immediately after the postorbital processes; ZB = zygomatic breadth, largest breadth between zygomatic arches; GBB = greatest breadth of braincase, measured at base of the squamosal roots; SCL, sagittal crest length, from temporal ridges convergence to the occipital crest; RBC, rostral breadth, at canines; IFB = breadth between infraorbital foramina; $\mathrm{GPB}=$ greatest palatal breadth, between the $4^{\text {nd }}$ premolar vestibular faces; GPL = palatal length, from anterior face of incisors to the posterior end of palatine; $\mathrm{CM} 1 \mathrm{~L}=\mathrm{C}$ to $\mathrm{M} 1$ toothrow length; P4L: greatest length of P4, from mesial to distal face; $\mathrm{P} 4 \mathrm{~B}=$ greatest breadth of $\mathrm{P} 4$, from lingual to vestibular face; $\mathrm{BL}=$ anteroposterior bullar length; $\mathrm{BM}=$ mastoid breadth, between mastoids; $\mathrm{TH}=$ temporal fossa height; $A L T=$ anteroposterior length of temporal fossa; $C L=$ upper canine length; $A L M=$ anteroposterior length of masseteric fossa; $\mathrm{p} 3 \mathrm{~m} 1 \mathrm{~L}=\mathrm{p} 3-\mathrm{m} 1$ toothhrow length; $\mathrm{MH}=$ mandibular ramus height; $\mathrm{ML}=$ mandible length, from lower incisor alveolus to angular process.

\section{Collection management}

When necessary, original labels were repaired and/ or enveloped with protective plastic and worn label lines replaced. All specimens were catalogued and mapped in Excel spreadsheet, in manner to mirror the arrangement inside the cabinets. The cabinets of the mammal collection are, as in several other old collections, disposed in pairs (one pair = one cabinet above another), and each pair side-by-side with others. The mapping of the cabinets was done by numbering in ascendant order from above to below and from left to right, while the inside arrangement was by numbering the drawers from the above to below. Aim verifying the keeping and increase of the collection, the specimens were verified with the catalogue of mammals of MPEG by Goeldi \& Hagmann (1906) and with the original books of collection numbers of ancient 'Museu Paraense'. It is important to mention that the first names of 'Museu Paraense Emilio Goeldi' were Museu Paraense (1866-1900) and 'Museu Goeldi' (1900-1931), and the first mammal specimens catalogued in the museum (from 1897 to 1946) received numbers that are different from most of those presently in the Mammal Collection.

\section{RESULTS}

\section{Catalogue of felid specimens}

Family Felidae in the MPEG is represented by 245 specimens distributed in four genera and nine species, all with localities in Brazil (Fig. 1, Table 1). The collection comprises opened and stuffed skins, skulls, and parts of the body, such as feet. Some specimens are unknown locality $(n=30)$, while 74 specimens are from 'Zoological 
Table 1. Number of specimens of Felidae present in the mammal collection of the Museu Paraense Emilio Goeldi. Locality includes acronyms of federative unities of Brazil, as follow: $A C=A c r e, A M=$ Amazonas, $A P=$ Amapá, $C E=$ Ceará, $M A=$ Maranhão, $M T=$ Mato Grosso, $P A=$ Pará, $\mathrm{RO}=$ Rondônia, $\mathrm{RR}=$ Roraima $\mathrm{RS}=$ Rio Grande do Sul, $\mathrm{TO}=$ Tocantins. $\mathrm{N}=$ number of specimens with locality. Zoological Garden and Parque Zoobotânico MPEG are specimens from captivity.

\begin{tabular}{|c|c|c|c|c|c|}
\hline Taxon & Locality & $\mathbf{N}$ & $\begin{array}{l}\text { Zoolo- } \\
\text { gical } \\
\text { Garden }\end{array}$ & $\begin{array}{l}\text { Parque } \\
\text { Zoobo- } \\
\text { tânico } \\
\text { MPEG }\end{array}$ & $\begin{array}{c}\text { Unknown } \\
\text { locality }\end{array}$ \\
\hline \multicolumn{6}{|l|}{ Genus Herpailurus } \\
\hline H. yagouaroundi & $\mathrm{PA}, \mathrm{RS}$ & 20 & 2 & 1 & 3 \\
\hline \multicolumn{6}{|l|}{ Genus Leopardus } \\
\hline L.emiliae & CE, MA, PA & 3 & & & \\
\hline L.geoffroyi & RS & 3 & & & \\
\hline L. guttulus & MT, RS & 2 & & & \\
\hline L. pardalis & $A C, A P, A M, C E, M A, P A, R R$ & 32 & 25 & & 8 \\
\hline L. tigrinus & RO & 1 & & & \\
\hline L. wiedii & $A M, M A, P A, R S$ & 15 & 25 & & 2 \\
\hline Leopardus sp. & MA & 1 & & & \\
\hline \multicolumn{6}{|l|}{ Genus Panthera } \\
\hline P.onca & AC, AP, MA, MT, PA, TO & 37 & 13 & 3 & 10 \\
\hline \multicolumn{6}{|l|}{ Genus Puma } \\
\hline P. concolor & $A C, A P, A M, M A, P A$ & 25 & 3 & 2 & 7 \\
\hline Total & 11 & 139 & 68 & 6 & 30 \\
\hline
\end{tabular}

Garden' and Parque Zoobotânico do MPEG (Table 1). It is probable that 'Zoological Garden' (= Jardim Zoológico) refers to the Parque Zoobotânico do MPEG, sited at Belém, Pará state, Brazil. However, since there is no additional information on the original labels and hard-copy catalogue volumes, a decision on the source of this material was not possible.

Country is in uppercase, state in bold, and municipality and precise locality in lower case. Between parenthesis information about sex (female, male or unknown) and preparation type (skin, skull, postcranium skeleton and/ or anatomical pieces). Gazetteer of localities and coordinates are available in the Appendix I and external and craniodental measurements of the specimens are in the Appendix II.

\section{Family Felidae Fisher, 1817 \\ Herpailurus Severtzov, 1858 \\ Herpailurus yagouaroundi \\ (É. Geoffroy Saint-Hilaire, 1803)}

Common names: Eyra Cat (English); Jaguarundi, Gatomourisco (Brazilian Portuguese).

Localities: BRAZIL, 20 specimens (Fig. 2): Amapá: Rio Araguary (= Rio Araguari; see Comments 1, below): MPEG 6819 (male, skull). Pará: Il has do Pará (= Marajó archipelago): MPEG 150 (male, skull); Ipixuna do Pará: MPEG 38326 (unknown sex, skin); Monte Alegre, baixo Amazonas: MPEG 149 (male, skull; see Comments 2, below); Monte Alegre, Colônia (agrícola) Inglês de Souza: MPEG 670 (male, skin and skull); Muaná, Ilha do Marajó, Rio São

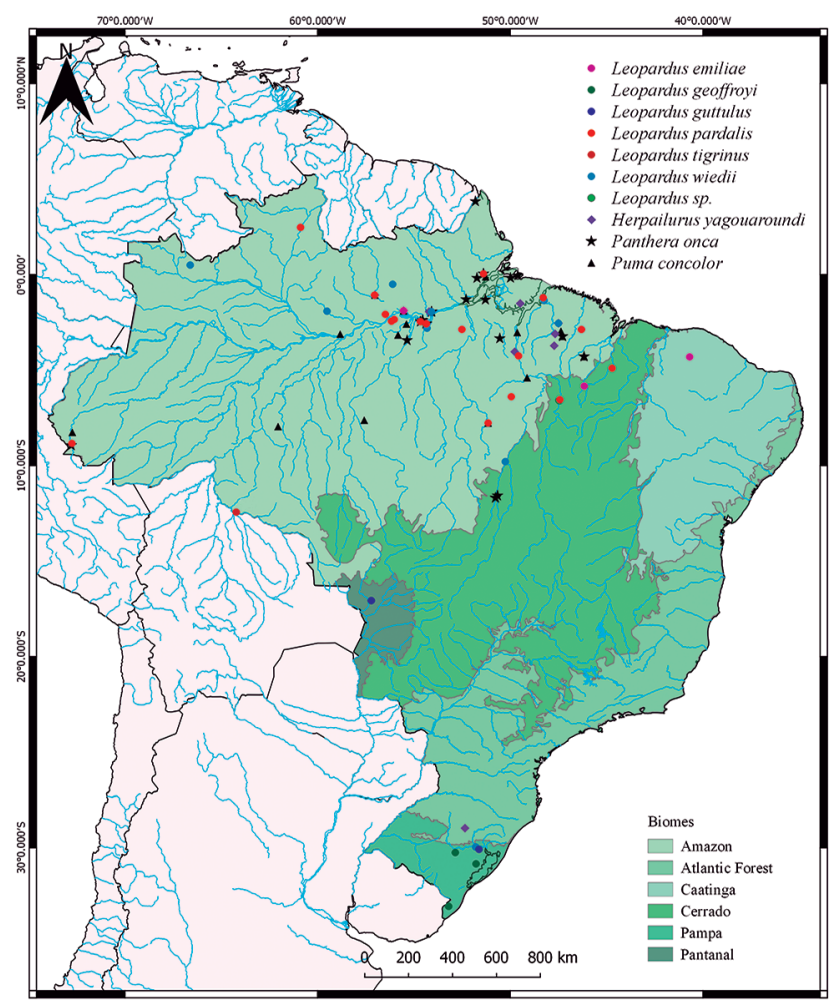

Figure 1. Map of biomes of the Brazil with all wild felid specimens, with accurate locality data, housed in the Museu Paraense Emilio Goeldi.

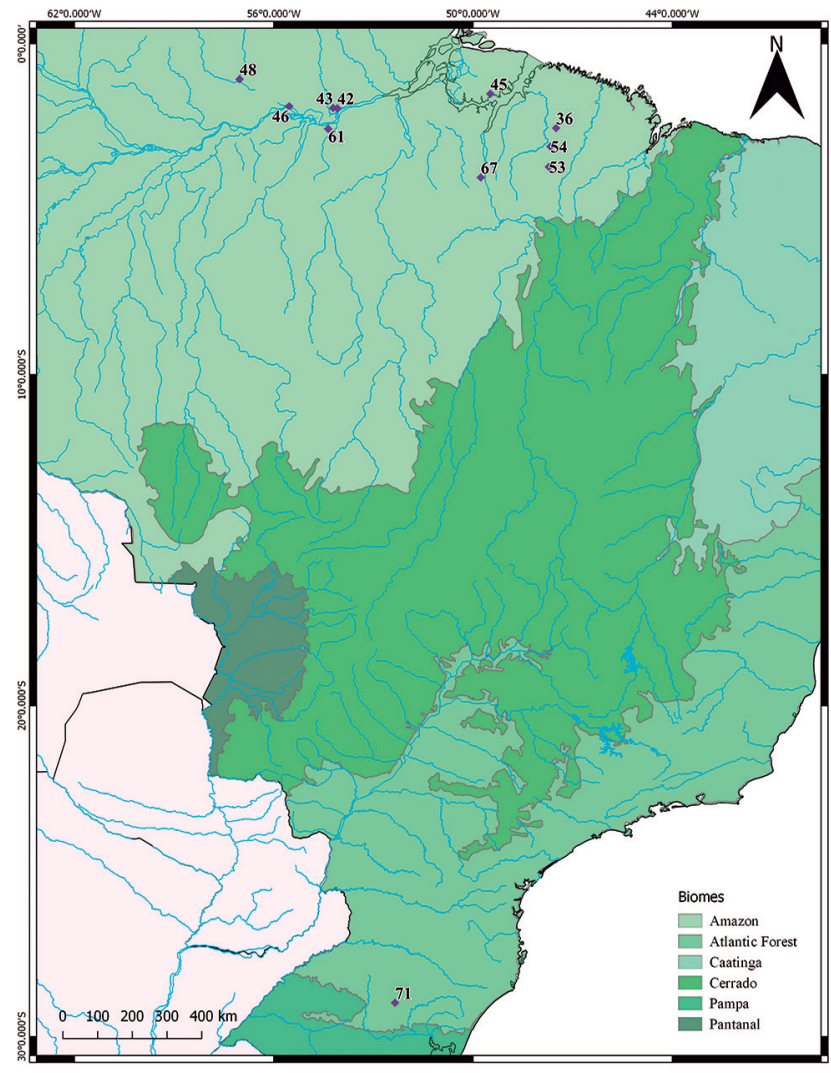

Figure 2. Localities of Herpailurus yagouaroundi at the Museu Paraense Emilio Goeldi.

Miguel, fazenda São Miguel: MPEG 25399 (unknown sex, skull and postcranium); Óbidos: MPEG 5642 (male, skull), MPEG 5645 (female, skull); Oriximiná, cachoeira Porteira, estrada de acesso à Perimetral Norte, alto Rio Trombetas: 
MPEG 10206 (female, skin and skull); Paragominas, Rio Gurupizinho, fazenda Cupuaçu: MPEG 11834 (male, skin); Paragominas, Vale S/A, Estrada Mineração: MPEG 40981 (male, skin); Santarém, Taperinha: MPEG 5616 (male, skull), MPEG 5633 (female, skull), MPEG 5643 (male, skull), MPEG 5644 (male, skull), MPEG 5646 (male, skull), MPEG 5647 (male, skull), MPEG 5648 (male, skull); Tucuruí, Rio Tocantins, margem esquerda: MPEG 22614 (male, skin). Rio Grande do Sul: Fontoura Xavier: MPEG 22202 (male, skin). Jardim Zoológico (Zoological Garden), 2 specimens: MPEG 4147 (female, skull), MPEG 4128 (male, skull). Parque Zoobotânico Emilio Goeldi, Belém, Pará, BRAZIL, 1 specimen: MPEG 10244 (female, skin, skull and postcranium). Unknown locality, 3 specimens: MPEG 6498, MPEG 6500 (females, skull); MPEG 6503 (male, skull).

\section{Comments:}

1) MPEG 6819 only with locality "Rio Araguary"; there are two rivers with the name "Rio Araguari", one near to Macapá, capital state of Amapá, another in Minas Gerais state, with headwaters in Serra da Canastra National Park flowing north into Paranaíba River, Goiás state border, central Brazil. Is probable that this specimen and the $P$. onca MPEG 6508 are both originate from this former region.

2) In Goeldi \& Hagmann's catalogue (1906) the number 149 (= 'n. 149', pag. 66) refer to a Felis onça 'ad litteram' (= Panthera onca). In the catalogue book of skulls of the ancient 'Museu Paraense', the specimen number 149 has the same data of the $H$. yagouaroundi specimen MPEG 149.

3) H. yagouaroundi is considered Vulnerable in Brazil, (DOU, 2014), and is included in CITES Appendix II (CITES, 2017) due danger of be hunting for trade. Loss habitat and fragmentation considered as forthcoming threats (IUCN, 2017).

\section{Leopardus Gray, 1842}

\section{Leopardus emiliae (Thomas, 1914)}

Common names: tigrina, oncilla, little spotted cat (English); gato-do-mato-pequeno (Brazilian Portuguese).

Localities: BRAZIL, 3 specimens (Fig. 3): Ceará: Ipú: MPEG 588 (male skin). Maranhão: Grajaú, Boa Lembrança, Sítio Novo, margem direita de Grajaú: MPEG 22685 (male, skin). Pará: Óbidos: MPEG 5618 (unknown sex, skull).

\section{Comments:}

1) MPEG 588 and MEPG 22685 have removed skin samples and MPEG 5618 muscle sample for molecular analysis by C.C. Sartor, in May 2017, for her doctoral dissertation developed at University Federal of Rio Grande do Sul;

2) Nascimento \& Feijó (2017) referred MPEG 588 as topotype of Felis emiliae based on Thomas (1914);
3) Recently recognized as full species, L. emiliae was junior synonym of L. tigrinus and is endemic of Brazil, with populations known from north, at right bank of Amazon River, throughout northeastern and central portion of this country (Nascimento \& Feijó, 2017). Leopardus tigrinus (sensu lato) is considered as Endangered in Brazil (DOU, 2014), globally Vulnerable

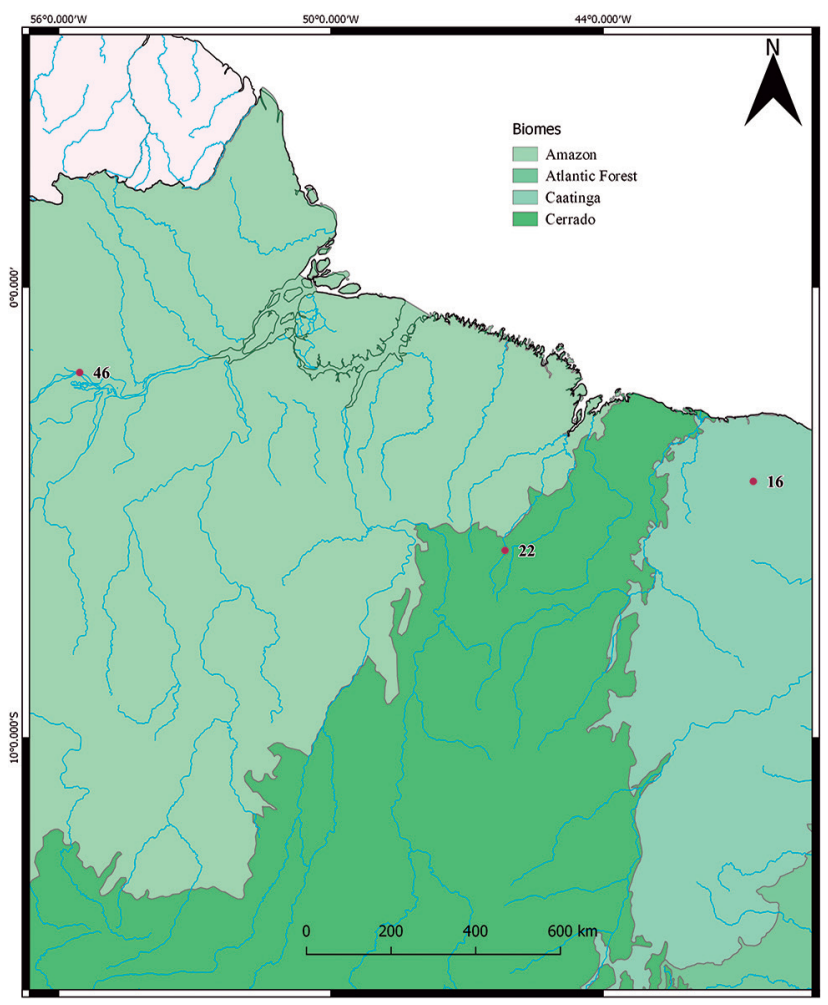

Figure 3. Localities of Leopardus emiliae at the in Museu Paraense Emilio Goeldi.

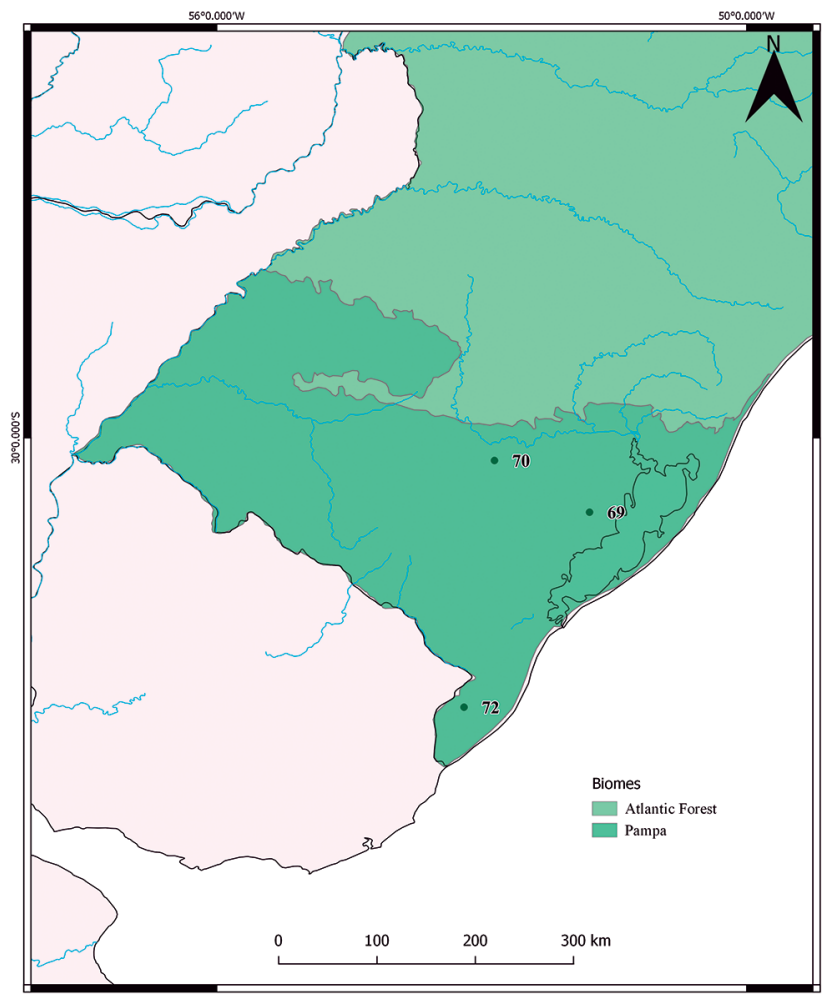

Figure 4. Localities of Leopardus geoffroyi at the Museu Paraense Emilio Goeldi. 
due current trending of decreasing population (IUCN, 2017), and included in CITES Appendix I (CITES, 2017), altogether before recognizing of three full species in tigrinus species group (L. emiliae, L. guttulus, and L. tigrinus), and respective restricted geographic distribution for each taxon (Nascimento \& Feijó, 2017). It is probable that L. emiliae and the other two species be included in a higher endangered category in the next endangered species list revisions.

\section{Leopardus geoffroyi (d'Orbigny and Gervais, 1844)}

Common names: Geoffroy's cat (English), gato-do-mato-grande (Brazilian Portuguese).

Localities: BRAZIL, 3 specimens (Fig. 4): Rio Grande do Sul: Arambaré/Camaquã divisa (Camaquã, Arambare in specimen label): MPEG 22184 (male, skull and skin); Cachoeira do Sul, BR 290: MPEG 22228 (female, skull); Rio Grande, Vila Mirim: MPEG 22201 (female, skull and skin).

\section{Comments:}

1) MPEG 22184, MPEG 22201 and MPEG 22228 have removed muscle samples for molecular analysis by C.C. Sartor, in May 2017, for her doctoral dissertation developed at University Federal of Rio Grande do Sul;

2) Leopardus geoffroyi is considered as Vulnerable in Brazil (DOU, 2014) and is included in CITES Appendix I (CITES, 2017).

\section{Leopardus guttulus (Hensel, 1872)}

Common names: Southern tigrina (English), Gato-domato-pequeno (Brazilian Portuguese).

Localities: BRAZIL, 2 specimens (Fig. 5): Mato Grosso: Pantanal: MPEG 22193* (male, skin - skull number MPEG 23854*). Rio Grande do Sul: Eldorado do Sul, BR 290, km 141 (= 'Rio Pardo' in specimen label): MPEG 22183 (male, skull and skin).

\section{Comments:}

1) MPEG 22183 have removed sample brain and MPEG 23854 muscle sample for molecular analysis by C.C. Sartor, in May 2017, for her doctoral dissertation developed at University Federal of Rio Grande do Sul;

2) Endangered as described above for L. emiliae, this species is found in northeastern Argentina, southeast, south and center-western Brazil, and Paraguay (Nascimento \& Feijó, 2017).

\section{Leopardus pardalis (Linnaeus, 1758)}

Common names: Ocelot (English), Jaguatirica (Brazilian Portuguese).
Localities: BRAZIL, 33 specimens (Fig. 6): Acre: Marechal Thaumaturgo, Seringal Oriente, próximo à Vila Taumaturgo: MPEG 853 (female, skull). Amapá: Vila Nova, Rio Vila Nova: MPEG 1250 (female, skull). Amazonas: Baixo Amazonas: MPEG 600 (unknown sex, skin). Ceará: MPEG 145 (unknown sex, skull; see Comments 2, bellow). Maranhão: Aldeia Karawarenda, Reserva Indígena Alto Turiaçu: MPEG 22020 (unknown sex, skin); Esperantinópolis, Palmeiral: MPEG 26419 (unknown sex, skin); Estreito: MPEG 43744 (unknown sex, skin). Pará: Altamira: MPEG 8065 (unknown sex, skull), MPEG 42556 (unknown sex, skin); Canaã dos Carajás: MPEG 44610 (male, skin); Cumaru do Norte, Reserva Indígena Kayapó, Aldeia Gorotire: MPEG 22831 (unknown sex, skull); Juruti, comunidade Barroso: MPEG 38379 (unknown sex, skin and skull); Juruti, platô Capiranga: MPEG 31690 (unknown sex, skull); Juruti, Rio Mamuru (in the original la-

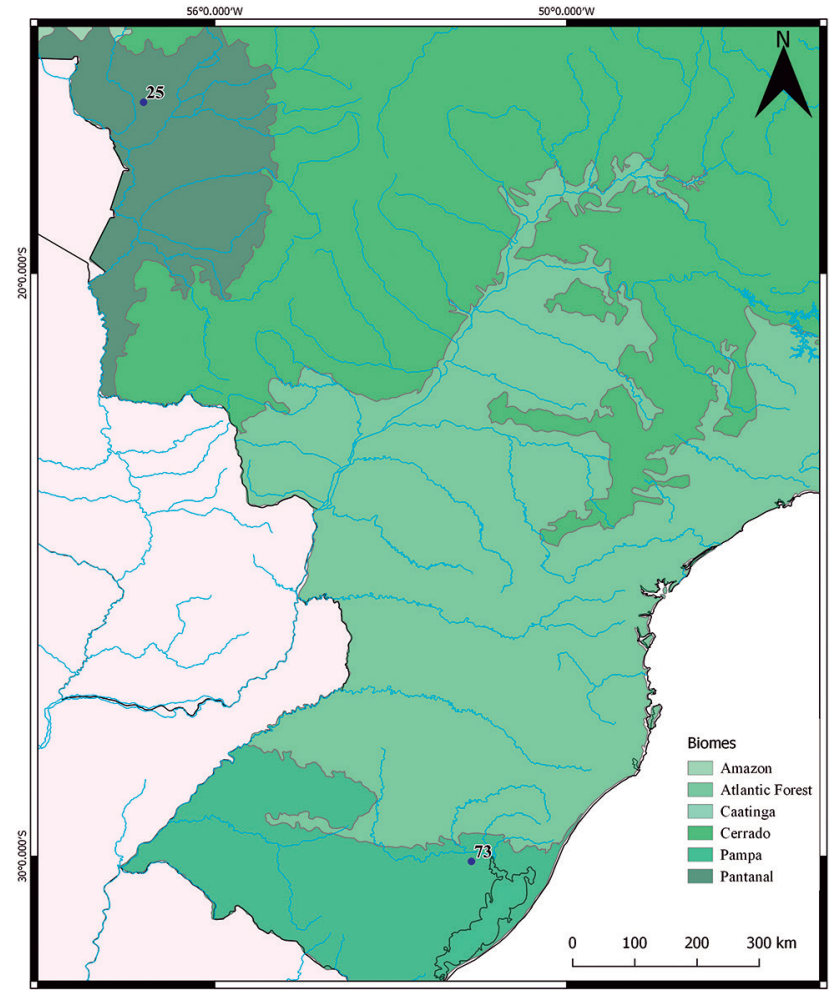

Figure 5. Localities of Leopardus guttulus at the Museu Paraense Emilio Goeldi.

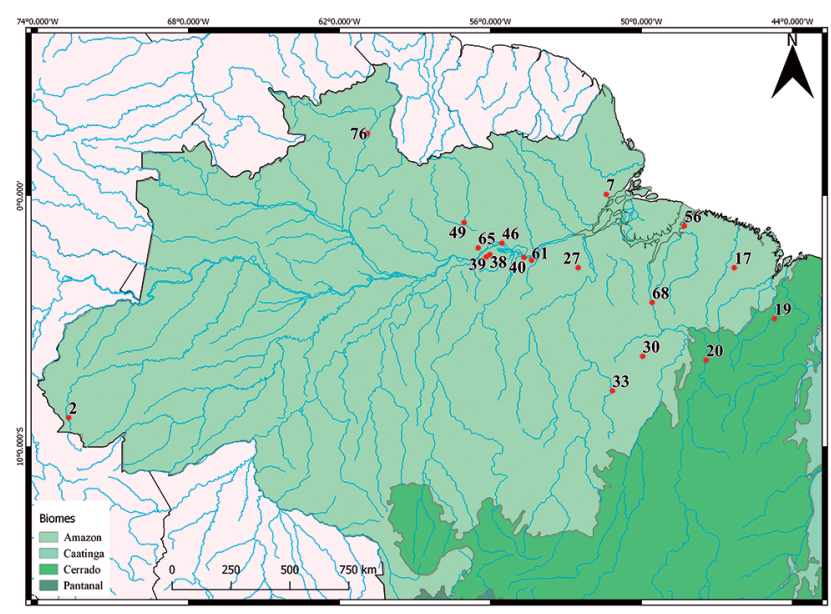

Figure 6. Localities of Leopardus pardalis at the Museu Paraense Emilio Goeldi. 
bel is Santarém, but the Rio Mamuru is at Juruti municipality): MPEG 41038 (unknown sex, skull), MPEG 41078 (unknown sex, skull and feet); Óbidos: MPEG 5641 (female, skull); Oriximiná, Cachoeira Porteira: MPEG 13309 (male, skull), MPEG 13310 (female, skull); Santa Bárbara do Pará, PA 391, Ramal do Araci, km 4: MPEG 37100 (unknown sex, skin); Santarém, Taperinha: MPEG 5610 (male, skull), MPEG 5620 (female, skull), MPEG 5634 (male, skull), MPEG 5635 (female, skull), MPEG 5636 (male, skull), MPEG 5637 (female, skull), MPEG 5638 (female, skull), MPEG 5639 (male, skull), MPEG 5640 (female, skull); Santarém, Iriri, "Frei": MPEG 41025 (unknown sex, skull); Terra Santa: MPEG 5609 (male, skull); Tucuruí, Vila Brabo, 56 km S de Tucuruí, margem direita do Rio Tocantins: MPEG 11894 (unknown sex, skull and postcranium). Roraima: Mucajaí, T.F. do Rio Branco, baixo Rio Mucajai: MPEG 1637 (unknown sex, skull), MPEG 2231 (unknown sex, skull and postcranium). Jardim Zoológico (Zoological Garden), 25 specimens: MPEG 4135, MPEG 4152, MPEG 4163, MPEG 4165-4167, MPEG 4169, MPEG 4171, MPEG 4178-4180 (females, skull); MPEG 4151, MPEG 4153, MPEG 4155, MPEG 4157-4161, MPEG 4164, MPEG 4176, MPEG 4181, MPEG 4182 (males, skull); MPEG 4148, MPEG 4149 (unknown sex, skull). Unknown locality, 8 specimens: MPEG 4150, MPEG 4177, MPEG 4183, MPEG 6501, MPEG 6507 (males, skull); MPEG 4156, MPEG 4162 (females, skull).

\section{Comments:}

1) MPEG 41025 was collected in Trairão or Uruará municipality (Elildo Carvalho Jr., specimen's collector, pers. comm. March 2018). Thus "Santarém, Iriri, Frei" probably is a mistranslated data for the catalogue book, since Iriri River is ca. 195 km southeastern far from Santarém municipality;

2) In the Goeldi \& Hagmann's catalogue (1906) the number 145 (= 'n. 145', pag. 65) refer to a Felis concolor (= Puma concolor). In two ancient catalogues of 'Museu Paraense' the specimen number 145 is identified as 'Felis' and as 'Felis concolor', respectively, from Ceará state, with passage by Zoological Garden (= 'Ceará, Jardim Zool.') from 17/II/1900 to 06/VII/1911.

3) Leopardus pardalis is included in CITES Appendix I (CITES, 2017).

\section{Leopardus tigrinus (Schreber, 1775)}

Common names: Northern Tiger Cat (English), Gato-domato-pequeno (Brazilian Portuguese).

Localities: BRAZIL, 1 specimen (Fig. 7): Rondônia: Costa Marques, BR 429: MPEG 42973 (unknown sex, skin) (Fig. 8).

\section{Comments:}

1) This is the only L. tigrinus specimen present in the MPEG's mammal collection and, to our knowledge, is the first record for the Brazilian state of Rondônia, collected in lowland Open Ombrophylous Forest (IBGE, 1992);
2) The specimen have removed skin sample for molecular analysis by C.C. Sartor, in May 2017, for her doctoral dissertation developed at University Federal of Rio Grande do Sul;

3) Leopardus tigrinus (sensu lato) is considered as Endangered in Brazil (DOU, 2014), globally Vulnerable due current trending of decreasing population (IUCN, 2017), and included in CITES Appendix I (CITES, 2017). See comments for L. emiliae.

\section{Leopardus wiedii (Schinz, 1821)}

Common names: Margay (English), Gato-maracajá (Brazilian Portuguese).

Localities: BRAZIL, 15 specimens (Fig. 9): Amazonas: MPEG 473 (female, skin); São Gabriel da Cachoeira, Parque Nacional do Pico da Neblina, BR 307, km 80, comunidade Parintins: MPEG 43029 (unknown sex, skin); São Sebastião do Uatumã, UHE Balbina, Rio Uatumã: MPEG 22156 (female, skin and skull). Maranhão: Aldeia Gurupiúna, Reserva Indígena Alto Turiaçu: MPEG 22021 (unknown sex, skin). Pará: Benevides: MPEG 709 (male, skull); Ipixuna do Pará: MPEG 38327 (unknown sex, skin); Juruti, Rio Mamuru (in the original label is Santarém, but the Rio Mamuru is at Juruti municipality: MPEG 41093 (unknown sex, skin); Monte Alegre, Curral Grande: MPEG 5617 (male, skull); Óbidos/Oriximiná, Cachoeira da Paciência, Rio Cuminá, 'Cachoeira Paciência, Rio': MPEG 2161 (male, skull); Santarém, Curuá-Una, 44 km S e 40 km E de Santarém: MPEG 20204 (male, skull); Santarém: MPEG 5619 (female, skull), MPEG 5650 (female, skull), MPEG 5608 (male, skull); São João (= São João do Araguaia), Rio Araguaia: MPEG 428 (male, skin). Rio Grande do Sul: São Jerônimo, Conde: MPEG 22191 (female, skin and skull). Jardim Zoológico (Zoological Garden), 25 specimens: MPEG 4125, MPEG 4129, MPEG 4133, MPEG 4134, MPEG 4136, MPEG 4138, MPEG 4140, MPEG 4141, MPEG 4143, MPEG 4144, MPEG 4146, MPEG 4154, MPEG 6497, MPEG 6502 (females, skull); MPEG 4126, MPEG 4127, MPEG 4130-4132, MPEG 4137, MPEG 4139, MPEG 4142 (males, skull); MPEG 8860, MPEG 8862

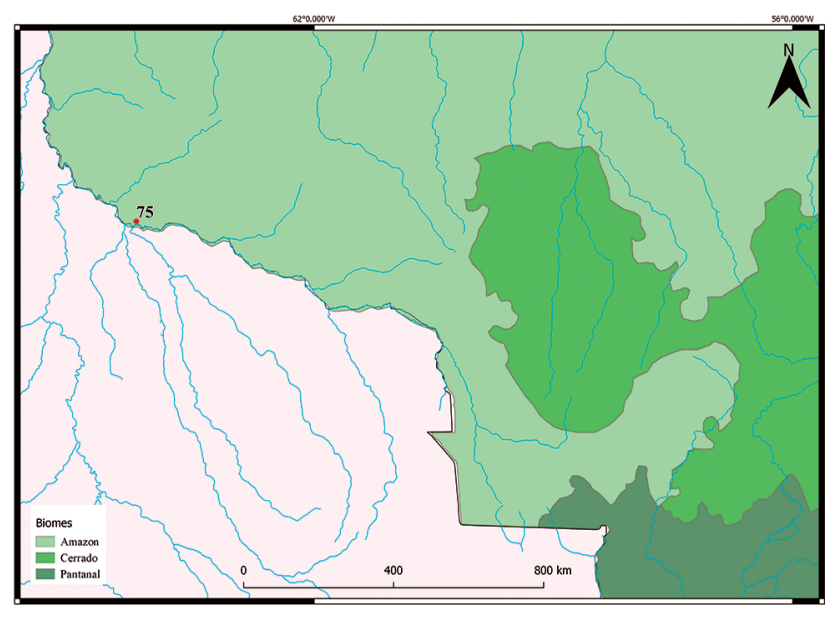

Figure 7. Locality of Leopardus tigrinus at the in Museu Paraense Emilio Goeldi. 


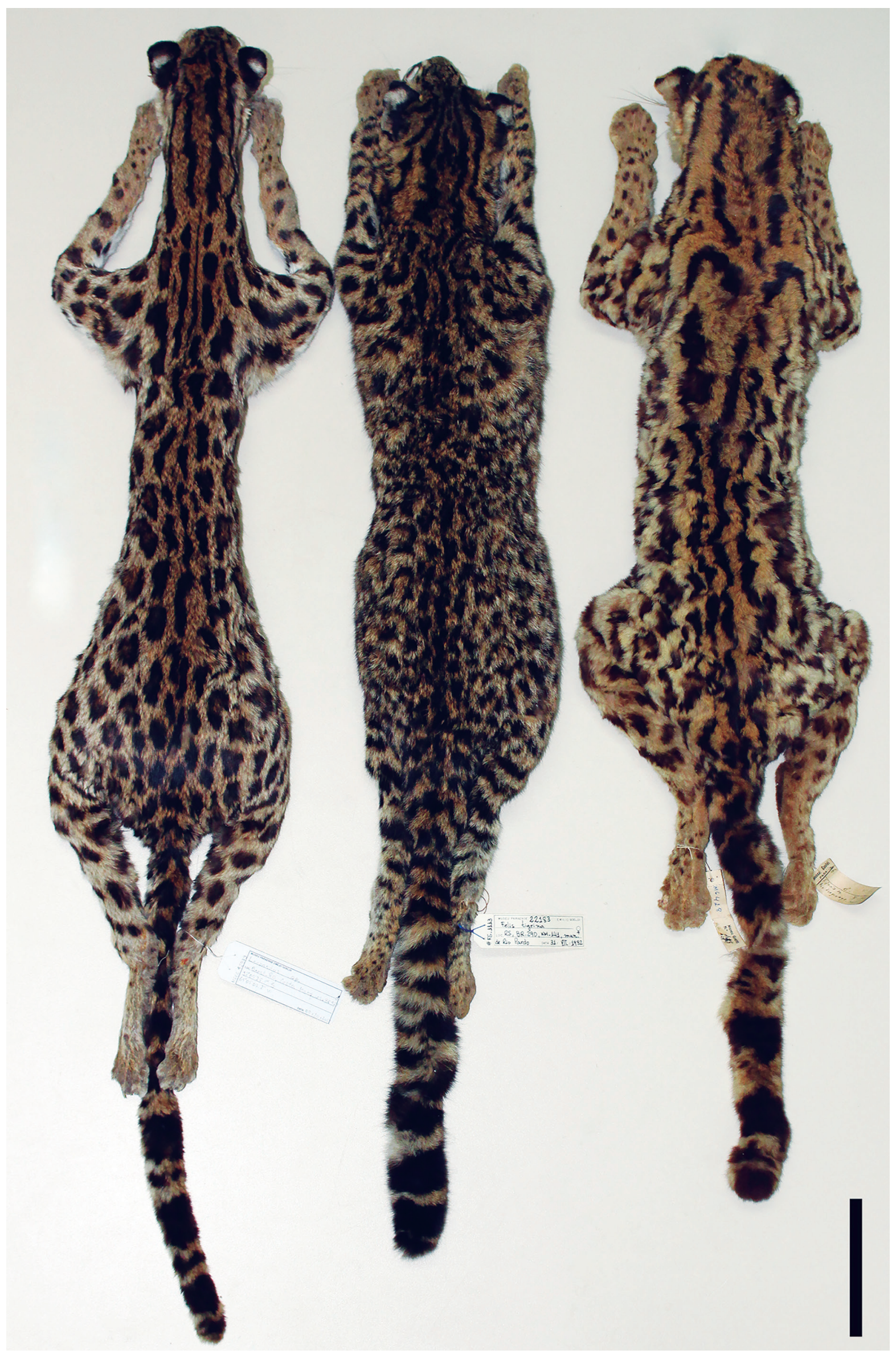

Figure 8. Representative of three comparable species of the genus Leopardus represented in the MPEG's mammal collection, showing patterns of ground coat and markings: Left: Leopardus tigrinus (MPEG 42973, BR 429, Costa Marques, Rondônia, Brazil); middle: L. guttulus (MPEG 22183, BR 290, km 141 [= 'Rio Pardo'], Eldorado do Sul, Rio Grande do Sul state, Brazil); right: L. wiedii (MPEG, 428, São João do Araguaia [São João], Rio Araguaia, Pará state, Brazil). Scale: 10 cm. 
(males with skin, skull and postcranium); MPEG 8863 (unknown sex, skull). Unknown locality, 2 specimens: MPEG 6505, MPEG 22376 (males, skull).

\section{Comments:}

1) Leopardus wiedii is considered as Vulnerable in Brazil (DOU, 2014), Near Threatened in IUCN Red List due

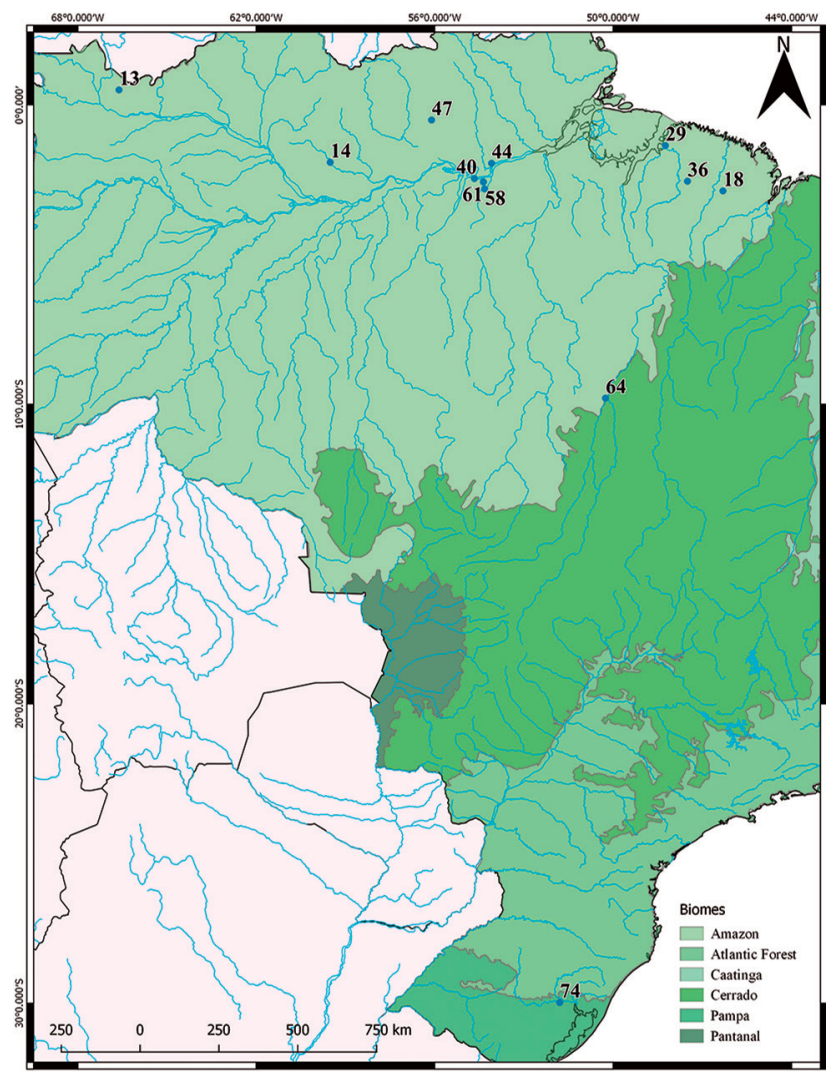

Figure 9. Localities of Leopardus wiedii at the Museu Paraense Emilio Goeldi.

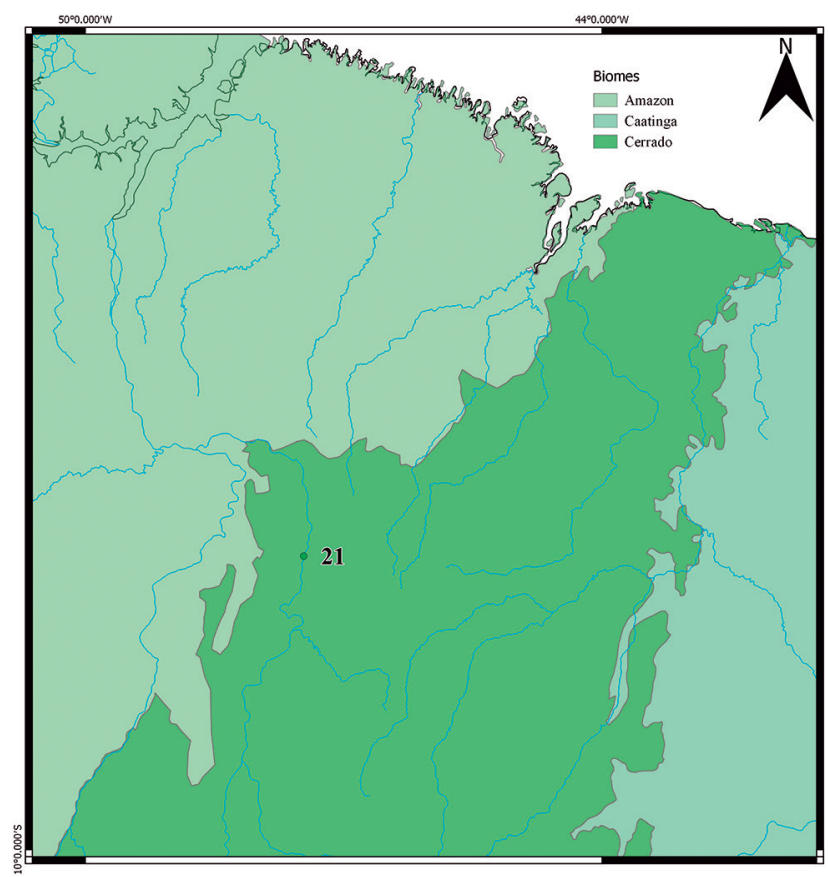

Figure 10. Locality of Leopardus sp. at the Museu Paraense Emilio Goeldi. population decline by habitat loss, fragmentation, roads, illegal trade, and retaliatory killing (IUCN, 2017), and is included in CITES Appendix I (CITES, 2017),

\section{Leopardus sp.}

Localities: BRAZIL, 1 specimen (Fig. 10): Maranhão: Estreito, UHE Estreito: MPEG 41510 (pup with unknown sex, skin).

\section{Comments:}

1) MPEG 41510 have removed skin sample for molecular analysis by C.C. Sartor, in May 2017, for her doctoral dissertation developed at University Federal of Rio Grande do Sul.

\section{Panthera Oken, 1816}

\section{Panthera onca (Linnaeus, 1758)}

Common names: jaguar (English), onça, onça-pintada (Brazilian Portuguese).

Localities: BRAZIL, 37 specimens (Fig. 11): Acre: Marechal Thaumaturgo, Vila Taumaturgo, Rio Juruá: MPEG 855 (unknown sex, skull). Amapá: Mazagão, Rio Maracá, igarapé Grande: MPEG 1954 (male, skull); Oiapoque: MPEG 1343 (unknown sex, skull); Rio Araguarí (see comments 1 in H. yagouaroundi): MPEG 6508 (male, skin). Santana, Rio Vila Nova: MPEG 2145 (unknown sex, skull), MPEG 2149 (female, skull). Maranhão: Santa Luzia, Fazenda Lagoinha, km 100 BR MA-74: MPEG 23296 (unknown sex, skin and skull). Mato Grosso: MPEG 6510 (female, skin). Pará: Almeirim, Saracura: MPEG 5664 (male, skull); Chaves, Ilha Mexiana: MPEG 112 (female, skull); Chaves, Ilha do Marajó, igarapé Taperebá: MPEG 1344 (unknown sex, skull); Gurupá, Resex de Gurupá-Melgaço: MPEG 42813 (unknown sex, skin); Juruti, Rio Mamuru (in the original label is 'Santarém' municipality, but the Rio Mamuru is at Juruti municipality): MPEG 41077 (unknown sex, left forefoot); Monte Alegre, Curral Grande: MPEG 5666 (male, skull), MPEG 5667 (female, skull), MPEG 5669 (female, skull), MPEG 5670 (male, skull); Paragominas, Paragominas, 25 km Sul: MPEG 30685 (unknown sex, skin); Santarém, Rio Tapará-miry: MPEG 5654 (male, skull); Portel, Rio Aruanã (in original label is "Anapu, Rio Aruanã", but Rio Aruanã, a river and also a village, are located in upper Pacajás River and not cross the Anapu municipality, being Portel the largest administrative unit along this river and where is Rio Aruanã village): MPEG 42814 (unknown sex, skull); Santarém, (Rio) Ituqui ('Rio Ituquy'): MPEG 5612 (female, skull), MPEG 5655 (male, skull); Santarém, (Rio) Tapajós, Escrivão, Resex TapajósArapiuns: MPEG 41019 (unknown sex, skull); Santarém, Taperinha: MPEG 5598 (unknown sex, skull), MPEG 5653 (male, skull), MPEG 5656 (male, skull), MPEG 5657 
(male, skull), MPEG 5658 (male, skull), MPEG 5659 (female, skull), MPEG 5660 (male, skull), MPEG 5661 (male, skull), MPEG 5662 (male, skull), MPEG 5663 (male, skull), MPEG 5665 (male, skull). Tocantins: Rio Araguaia: MPEG 529 (female, skull), MPEG 528 (male, skull); Santa Isabel, Ilha do Bananal (= Lagoa da Confusão, Santa Isabel do Morro, Ilha do Bananal): MPEG 1016 (unknown sex, skull). Jardim Zoológico (Zoological Garden), 13 specimens: MPEG 4168, MPEG 4172, MPEG 4173, MPEG 4186, MPEG 4187, MPEG 4189 (females, skull); MPEG 6496 (female, skin and skull); MPEG 4170, MPEG 4174, MPEG 4175, MPEG 4185, MPEG 4188 (males, skull); MPEG 6499 (male, skin). Parque Zoobotânico Emilio Goeldi, Belém, Pará, BRAZIL, 3 specimens: MPEG 10243 (unknown sex, skin, skull, postcranium); MPEG 21708 (male, skin); MPEG 21709 (female, skull, postcranium). Unknown locality, 10 specimens: MPEG 22399, MPEG 30686 (males, skull); MPEG 30687 (female, skull, postcranium); MPEG 22394-22398, MPEG 30691 (unknown sex, skull); MPEG 42634 (unknown sex, skin).

\section{Comments:}

1) Panthera onca is considered as Vulnerable in Brazil (DOU, 2014), Near Threatened in IUCN Red List due to suspected decline populations by habitat loss, fragmentation, illegal trade, and retaliatory hunting (IUCN, 2017), and is included in CITES Appendix I (CITES, 2017).

\section{Puma Jardine, 1834}

\section{Puma concolor (Linnaeus, 1771)}

Common names: muontain lion, puma, cougar (English), onça-parda, suçuarana (Brazilian Portuguese).

Localities: BRAZIL, 25 specimens (Fig. 12): Acre: Porto Walter, Seringal, Triunfo, margem esquerda Rio Juruá: MPEG 24121 (unknown sex, skull). Amapá: Mazagão, (Seringal) Boa Fortuna, alto Igarapé Rio Branco: MPEG 1665 (female, skin and skull); Santana, Rio Vila Nova: MPEG 2146 (unknown sex, skull). Amazonas: Humaitá, BR 230, km 104 (Humaitá-Apuí), margem esquerda do Rio dos Marmelos: MPEG 23155 (unknown sex, skin); Itacoatiara (in original label is 'Manaus' municipality, but the Urubu River not cross this municipality), Praia do Cachorro, Rio Urubú: MPEG 7110 (male, skin and skull). Maranhão: Santa Luzia, Fazenda Lagoinha, km 100, BR MA-74: MPEG 23297 (unknown sex, skull). Pará: Baião, Vila Ituquara (= São Joaquim do Ituquara): MPEG 38325 (unknown sex, skin); Cumaru do Norte, Reserva Indígena Kayapó, Aldeia Gorotire Posto Indígena Aukre: MPEG 22855 (unknown sex, skull); Jacareacanga, Missão do Cururu: MPEG 5600 (female, skull); Marabá: MPEG 6511 (male, skin and skull); Monte Alegre, Curral Grande: MPEG 5668 (male, skull); Óbidos: MPEG 5596 (female, skull), MPEG 5597 (female, skull); Oriximiná, Cachoeira Porteira, estrada de acesso à Perimetral Norte, alto Rio Trombetas:
MPEG 10207 (female, skin and skull); Paragominas: MPEG 28685 (unknown sex, skin); Paragominas, 20 km S: MPEG 30684 (unknown sex, skull); Santarém, (Rio) Arapiuns, Aningalzinho, Resex Tapajós-Arapiuns: MPEG 41021 (unknown sex, skull); Santarém, Maró, Porto Rico, Resex Tapajós-Arapiuns: MPEG 41020 (unknown sex, skull); Santarém, Taperinha: MPEG 5593 (male, skull), MPEG 5594 (male, skull), MPEG 5595 (male, skull), MPEG 5599 (female, skull), MPEG 5601 (male, skull), MPEG 5606 (male, skull), MPEG 5607 (male, skull). Jardim Zoológico (Zoological Garden), 3 specimens: MPEG 4184, MPEG 4190, MPEG 6509 (females, skull). Parque Zoobotânico Emilio Goeldi, Belém, Pará, BRAZIL, 2 specimens: MPEG 7903 (female, skin and skull), MPEG 8063 (unknown sex, skin and skull). Unknown locality, 7 specimens: MPEG 4191 (male, skull); MPEG 22389 (female, skull); MPEG 6504, MPEG 22390-22392, MPEG 28690 (unknown sex, skull).

\section{Comments:}

1) Puma concolor is considered as Vulnerable in Brazil (DOU, 2014) and is included in CITES Appendix I (CITES, 2017).

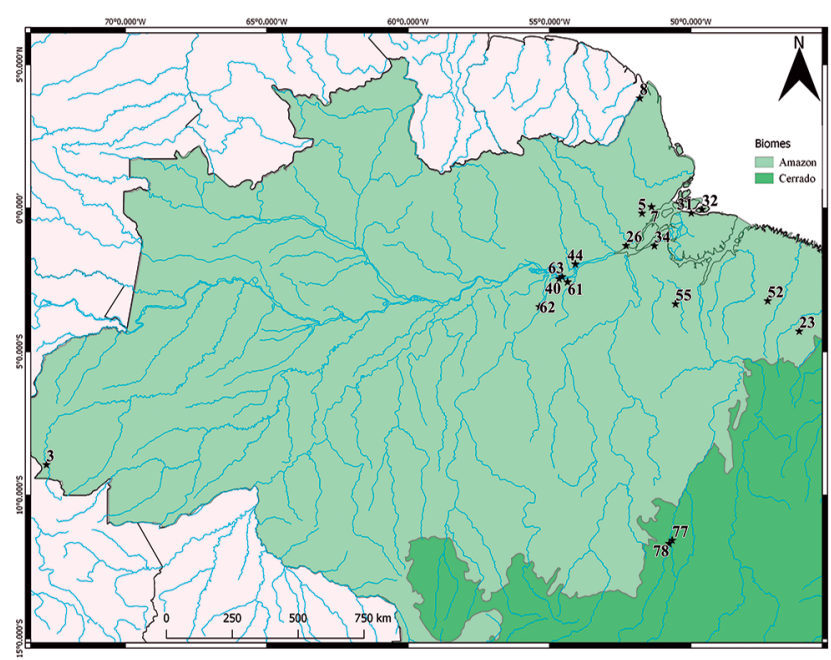

Figure 11. Localities of Panthera onca at the Museu Paraense Emilio Goeldi.

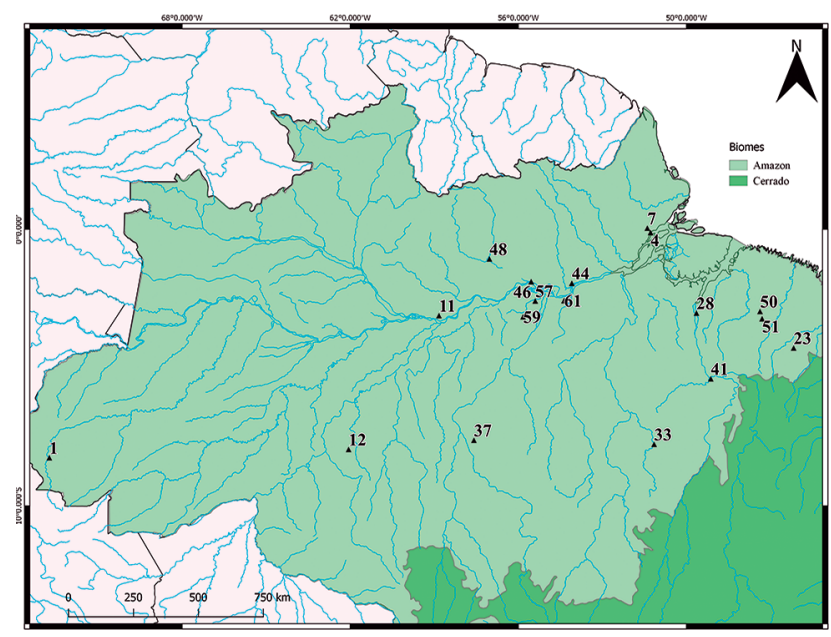

Figure 12. Localities of Puma concolor at the Museu Paraense Emilio Goeldi. 


\section{DISCUSSION AND CONCLUSION}

This catalogue represents the status of the MPEG mammal collection in early 2018. Currently, are recognized 10 wild felid species for the Brazil (Kitchener et al., 2017; Nascimento \& Feijó, 2017), almost all represented in the collection, excluding L. colocola (Molina, 1782). A large number of felid specimens (almost $30 \%$ of the collection) are either from 'Zoological Garden' and 'Parque Zoobotânico do MPEG'. There are in the MPEG's mammal collection several other specimens of other taxonomic groups (e.g., canids, artiodactyls) that are also from 'Zoological Garden' and 'Parque Zoobotânico do MPEG'. A further interesting project could focusing in tracking the origin of all these samples, since zoological gardens usually have a strict stock control of origin of the animals.

Goeldi \& Hagmann's catalogue (1906) mention to 65 felid specimens, but only 16 them with museum numbers directly linked. The MPEG's mammal collection has at least four independent book catalogues for the museum numbers since the institution foundation: one for the skulls, numbered from 1 to 2,186 (from year 1903 to 1946); one for the skins, numbered from 1 to 646 (from year 1901 to 1946); one general, numbered from 1 to 336 (from year 1897 to 1902); and a recent book, with 14 volumes, so including the acronym MPEG, with numbers from 1 to 45,560 (numbers verified in June 2018). In this way, was not possible make a trusty link among all the specimens mentioned by Goeldi \& Hagmann (1906) and those from the book specimens of MPEG's mammal collection. In fact, among the specimens verified in this study only two them, MPEG 145 and MPEG 149, are in the Goeldi \& Hagmann' catalogue (1906), being the latter as a distinct species. It is possible that the other specimens were dispersed along the years from early to half $20^{\text {th }}$ century, when some collections in the institution had no curator.

In addition, is brought to light the first empirical record of L. tigrinus from Rondônia state, enlarging their distribution into southwestern Brazilian Amazonia. Oliveira et al. (2013) have listed L. tigrinus for conservation unities of Rondônia state and the CENAP Database as source (CENAP = Centro Nacional de Pesquisa e Conservação de Mamíferos Carnívoros, and ICMBio department). However, after to contact the CENAP through a member staff (Paula A. Conde, at 12 April, 2018), it was not possible found either data or vouchers for these records.

Neotropical felids are among the most endangered Mammalia taxa, which also are under restrictive laws of collection for scientific purposes. This catalogue will be a valuable tool for a more complete use of specimens housed in the MPEG's mammal collection.

\section{ACKNOWLEDGMENTS}

We are thanks to J.S. Silva Jr. "Cazuza" for granted complete access to the collection, and to Airton da Luz, Celso Moraes, and Raimundo "Dico" for assistance in the collection. Suely A. Marques-Aguiar gently aided us with the access and information about the ancient catalogue books of MPEG. Elildo Carvalho Jr and Paula A. Conde (CENAP/ICMBio) gently elucidated some specimen localities. Fábio Nascimento critically reviewed the manuscript. ARB received research fellowship from DCRq/ CNPq (№ 300461/2016-0) and SOB an undergraduate fellowship from FAPESPA (№ 066/2016).

\section{REFERENCES}

Bezerra, A.M.R. 2012 (published in 2013). Coleções científicas de mamifferos: I - Brasil. Boletim da Sociedade Brasileira de Mastozoologia, 65: 19-25.

CITES - Convention on International Trade in Endangered Species of Wild Fauna and Flora. 2017. The CITES Appendices: Appendices I, II and III. Available at: www.cites.org/eng/app/index.php. Access in: 09/04/2018.

DOU - Diário Oficial da União. 2014. Portaria № 444, de 17 de dezembro de 2014. DOU, Seção 1, 245: 121-126. Available at: http://pesquisa. in.gov.br/imprensa/jsp/visualiza/index.jsp?jornal=1\&pagina $=121 \& d a$ $\mathrm{ta}=18 / 12 / 2014$. Access in: 09/04/2018.

FUNAI - Fundação Nacional do Índio. 2018. Terras Indígenas. Brasilia, DF, FUNAI/MJ. Available at: www.funai.gov.br/index.php/indios-no-brasil/ terras-indigenas. Access in: 09/04/2018.

Goeldi, E.A. \& Hagmann, G. 1906. Prodromo de um catalogo critico, commentado da colleç̧ão de mammiferos no Museu do Pará (1894-1903). Boletim do Museu Goeldi de Historia Natural eEthnographia, 4(1-4): 1-122.

Google Inc. 2018. Google Earth Pro. USA. Available at: https://earth.google. com/download-earth.html. Access in: 09/04/2018.

IBGE - Instituto Brasileiro de Geografia e Estatística. 1992. Shapes do Mapa de Vegetação do Brasil. Rio de Janeiro, IBGE. Available at: www.dpi.inpe.br/ Ambdata/mapa sipam.php. Access in: 09/04/2018.

IBGE - Instituto Brasileiro de Geografia e Estatística. 2018. Cidades@. IBGE, Rio de Janeiro. Available at: https://cidades.ibge.gov.br/xtras/home. php. Access in: 09/04/2018.

ICMBio - Instituto Chico Mendes de Conservação da Biodiversidade. 2018. Unidades de Conservação. Brasilia, DF, ICMBio/MMA. Available at: www. icmbio.gov.br/portal/unidadesdeconservacao/biomas-brasileiros. Access in: 09/04/2018.

IUCN - International Union for Conservation of Nature and Natural Resources. 2017. The IUCN Red List of Threatened Species, version 2017-3. Available at: www.iucnredlist.org. Access in: 09/04/2018.

Kitchener, A.C.; Breitenmoser-Wursten, Ch.; Eizirik, E.; Gentry, A.; Werdelin, L.; Wilting, A.; Yamaguchi, N.; Abramov, A.V.; Christiansen, P.; Driscoll, C.; Duckworth, J.W.; Johnson, W.; Luo, S.-J.; Meijaard, E.; O'Donoghue, P.; Sanderson, J.; Seymour, K.; Bruford, M.; Groves, C.; Hoffmann, M.; Nowell, K.; Timmons, Z. \& Tobe, S. 2017. A revised taxonomy of the Felidae. The final report of the Cat Classification Task Force of the IUCN/ SSC Cat Specialist Group. Cat News, Special Issue, 11: 3-79.

Nascimento, F.0. 2010. Revisão taxonômica do gênero Leopardus Gray, 1842 (Carnivora, Felidae). (Ph.D. Dissertation). São Paulo, Instituto de Biociências da Universidade de São Paulo, 358p.

Nascimento, F.0. 2014. On the morphological variation and taxonomy of the Geoffroy's cat Leopardus geoffroyi (D'Orbigny \& Gervais, 1844) (Carnivora, Felidae). Papéis Avulsos de Zoologia, 54(11): 129-160.

Nascimento, F.0. \& Feijó, A. 2017. Taxonomic revision of the tigrina Leopardus tigrinus (Schreber, 1775) species group (Carnivora, Felidae). Papéis Avulsos de Zoologia, 57(19): 231-264.

Oliveira, T.G.; Almeida, L.B. \& Beisiegel, B.M. 2013. Avaliação do risco de extinção do gato-do-mato Leopardus tigrinus (Schereber, 1775) no 
Brasil. Bio Brasil Biodiversidade Brasileira, Revista Centífica, 3(1): 56-65. (Número temático: Avaliação do estado de conservação dos crocodilianos e dos carnívoros). Available at: www.icmbio.gov.br/revistaeletronica/ index.php/BioBR/article/view/409. Access in 14/04/2018.

QGIS, 2017. QGIS 2.18.9 'Las Palmas.' Boston, MA, Free Software Foundation, Inc. Available at: www.qgis.org/en/site/forusers/download.html. Access in: 09/04/2018.

Sanjad, N. 2006. Emílio Goeldi (1859-1917) e a institucionalização das Ciências Naturais na Amazônia. Revista Brasileira de Inovação, 5: 455-477.
Silva, J.M.; Oren, D.C. \& Lima, M.F.C. 2005. Fernando Novaes: 0 fundador da moderna Ornitologia brasileira. Boletim do Museu Paraense Emílio Goeldi, série Ciências Naturais, 1(1): 249-254.

Sunquist, M.E. \& Sunquist, F.C. 2009. Family Felidae (Cats). In: Wilson, D.E. \& Mittermeier, R.A. (Eds.). Handbook of the Mammals of the World, Volume 1: Carnivores. Barcelona, Lynx Edicions. p. 54-169.

USGS - United State Geological Survey. 2017. Global Ecosystems: South America. Available at: https://rmgsc.cr.usgs.gov/ecosystems. Access in: 09/04/2018. 


\section{APPENDIX I}

\section{Gazetteer of localities and coordinates}

Country in uppercase, state in bold, and municipality and precise locality in lower case. Between parenthesis information about sex (female, male or unknown) and preparation type (skin, skull, postcranium and/or anatomical pieces). $\mathrm{N}=$ number of specimens.

For specimens with only municipality data in the label specimen or in the cataloguing book of collection specimens was used the coordinates of city/village/county.

\section{BRAZIL}

\section{Acre:}

1. Porto Walter, Seringal, Triunfo, margem esquerda do Rio Juruá $-08^{\circ} 15^{\prime} 28.9^{\prime \prime} \mathrm{S} 72^{\circ} 44^{\prime} 15.3^{\prime \prime} \mathrm{W}$

2. Marechal Thaumaturgo, Seringal Oriente, próximo à Vila Taumaturgo $-08^{\circ} 50^{\prime} 23^{\prime \prime} \mathrm{S} 72^{\circ} 45^{\prime} 32^{\prime \prime} \mathrm{W}$

3. Marechal Thaumaturgo, Vila Taumaturgo, Rio Juruá $-08^{\circ} 56^{\prime} 32.87^{\prime \prime} \mathrm{S} 72^{\circ} 47^{\prime} 31.12^{\prime \prime} \mathrm{W}$

\section{Amapá:}

4. Mazagão, (Seringal) Boa Fortuna, alto igarapé Rio Branco - 00 $07^{\prime} 06.6^{\prime \prime} S 51^{\circ} 16^{\prime} 45.0^{\prime \prime} \mathrm{W}$

5. Mazagão, Rio Maracá, igarapé Grande - $00^{\circ} 10^{\prime} 58.46^{\prime \prime} S 51^{\circ} 43^{\prime} 52.86^{\prime \prime} \mathrm{W}$ (from Maracá village)

6. Rio Araguary - without coordinates

7. Santana, Rio Vila Nova $-00^{\circ} 02^{\prime} 28.21^{\prime \prime} \mathrm{N} 51^{\circ} 23^{\prime} 38.00^{\prime \prime} \mathrm{W}$ (in middle Rio Vila Nova)

8. Oiapoque $-03^{\circ} 49^{\prime} 49^{\prime \prime} \mathrm{N} 51^{\circ} 48^{\prime} 39^{\prime \prime} \mathrm{W}$ (from city)

\section{Amazonas:}

9. Amazonas - without coordinates

10. Baixo Amazonas $-01^{\circ} 58^{\prime} \mathrm{S} 56^{\circ} 08^{\prime} \mathrm{W}-01^{\circ} 08^{\prime} \mathrm{S} 51^{\circ} 47^{\prime} \mathrm{W}$ (not depicted in the maps)

11. Itacoatiara, praia do Cachorro, Rio Urubu $-03^{\circ} 07^{\prime} 11.9^{\prime \prime} \mathrm{S} 58^{\circ} 49^{\prime} 54.5^{\prime \prime} \mathrm{W}$ (in middle Urubu River)

12. Humaitá, BR 230 , km 104 (Humaitá-Apuí), margem esquerda do Rio dos Marmelos - $07^{\circ} 57^{\prime} 27.59^{\prime \prime} S 62^{\circ} 03^{\prime} 24.00^{\prime \prime}$ W (in original label is 'Manicoré municipality', but it is to right edge of dos Marmelos River)

13. São Gabriel da Cachoeira, Parque Nacional do Pico da Neblina, BR 307, km 80, comunidade Parintins $-00^{\circ} 29^{\prime} 45.5^{\prime \prime} \mathrm{N} 66^{\circ} 37^{\prime} 02.4^{\prime \prime} \mathrm{W}$

14. São Sebastião do Uatumã, UHE Balbina, Rio Uatumã - $01^{\circ} 55^{\prime} 15.04^{\prime \prime} S 59^{\circ} 30^{\prime} 58.44^{\prime \prime} \mathrm{W}$ (from UHE dam)

\section{Ceará:}

15. Ceará - without coordinates

16. Ipú $-04^{\circ} 18^{\prime} 36^{\prime \prime} S 40^{\circ} 41^{\prime} 26^{\prime \prime} \mathrm{W}$

\section{Maranhão:}

17. Aldeia Karawarenda, Reserva Indígena Alto Turiaçu - 02 $52^{\prime} 29.29^{\prime \prime} \mathrm{S} 46^{\circ} 18^{\prime} 30.54^{\prime \prime} \mathrm{W}$ (from middle of reserve territory)

18. Aldeia Gurupiúna, Reserva Indígena Alto Turiaçu $-02^{\circ} 52^{\prime} 29.29^{\prime \prime} \mathrm{S} 46^{\circ} 18^{\prime} 30.54^{\prime \prime} \mathrm{W}$ (from middle of reserve territory)

19. Esperantinópolis, Palmeiral $-04^{\circ} 54^{\prime} 07.15^{\prime \prime} \mathrm{S} 44^{\circ} 42^{\prime} 56.77^{\prime \prime} \mathrm{W}$

20. Estreito $-06^{\circ} 33^{\prime} 10.31^{\prime \prime} S 47^{\circ} 25^{\prime} 48.76^{\prime \prime} \mathrm{W}$ (from city)

21. Estreito, UHE Estreito - $06^{\circ} 35^{\prime} 20^{\prime \prime} S 47^{\circ} 27^{\prime} 25^{\prime \prime} \mathrm{W}$ (from UHE dam)

22. Grajaú, (povoado) Boa Lembrança, Sítio Novo, margem direita de Grajaú - 0550'35"S 4609'45"W

23. Santa Luzia, Fazenda Lagoinha, km 100, BR MA-74-04 $17^{\prime} 30.9^{\prime \prime} \mathrm{S} 46^{\circ} 10^{\prime} 23.4^{\prime \prime} \mathrm{W}$

\section{Mato Grosso:}

24. Mato Grosso - without coordinates

25. Pantanal $-17^{\circ} 04^{\prime} S 57^{\circ} 13^{\prime} \mathrm{W}$ (in middle Pantanal of Mato Grosso state)

\section{Pará:}

26. Almeirim, costa da Saracura $-01^{\circ} 18^{\prime} 21.6^{\prime \prime} \mathrm{S} 52^{\circ} 17^{\prime} 48.6^{\prime \prime} \mathrm{W}$

27. Altamira $-02^{\circ} 52^{\prime} 21.97^{\prime \prime} \mathrm{S} 52^{\circ} 30^{\prime} 47.00^{\prime \prime} \mathrm{W}$ (from city)

28. Baião, Vila Ituquara (= São Joaquim do Ituquara) $-03^{\circ} 01^{\prime} 44.92^{\prime \prime} S 49^{\circ} 38^{\prime} 29.04^{\prime \prime} \mathrm{W}$ (from city)

29. Benevides - $01^{\circ} 21^{\prime} 41^{\prime \prime} S 48^{\circ} 14^{\prime} 41^{\prime \prime} \mathrm{W}$ (from city)

30. Canaã dos Carajás - 06 $23^{\circ} 52.32^{\prime \prime} S 49^{\circ} 56^{\prime} 57.16^{\prime \prime} \mathrm{W}$ (from city)

31. Chaves, Illha do Marajó, igarapé Taperebá - $00^{\circ} 10^{\prime} 20.01^{\prime \prime} S 49^{\circ} 59^{\prime} 26.44^{\prime \prime} \mathrm{W}$ (from city)

32. Chaves, Illha Mexiana $-00^{\circ} 02^{\prime} 59.1^{\prime \prime} \mathrm{S} 49^{\circ} 36^{\prime} 30.5^{\prime \prime} \mathrm{W}$ (in middle island)

33. Cumaru do Norte, Reserva Indígena Kayapó, Aldeia Gorotire $-07^{\circ} 46^{\prime} 14.79^{\prime \prime} S 51^{\circ} 09^{\prime} 08.95^{\prime \prime} \mathrm{W}$

34. Gurupá, Resex de Gurupá-Melgaço - $01^{\circ} 19^{\prime} 03.00^{\prime \prime} \ 51^{\circ} 17^{\prime} 35.22^{\prime \prime} \mathrm{W}$ 
35. Ilhas do Pará (= Marajó archipelago) - without coordinates

36. I pixuna do Pará - $02^{\circ} 33^{\prime} 03.63^{\prime \prime} S 47^{\circ} 30^{\prime} 07.17^{\prime \prime} \mathrm{W}$ (from city)

37. Jacareacanga, Missão do Cururu $-07^{\circ} 37^{\prime} 24.4^{\prime \prime} \mathrm{S} 57^{\circ} 35^{\prime} 01.5^{\prime \prime} \mathrm{W}$

38. Juruti, comunidade Barroso - 02 $21^{\circ} 10.70^{\prime \prime} \mathrm{S} 56^{\circ} 01^{\prime} 31.90^{\prime \prime} \mathrm{W}$

39. Juruti, platô Capiranga $-02^{\circ} 26^{\prime} 41^{\prime \prime} S 56^{\circ} 10^{\prime} 10^{\prime \prime} \mathrm{W}$

40. Juruti, Rio Mamuru - $02^{\circ} 27^{\prime} 49^{\prime \prime} \mathrm{S} 54^{\circ} 39^{\prime} 56^{\prime \prime} \mathrm{W}$

41. Marabá $-05^{\circ} 24^{\prime} 13.63^{\prime \prime} \mathrm{S} 49^{\circ} 07^{\prime} 47.08^{\prime \prime} \mathrm{W}$ (from city)

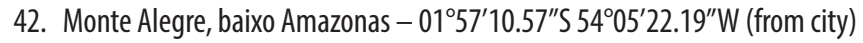

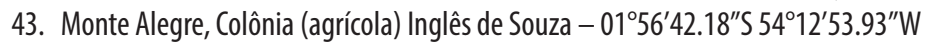

44. Monte Alegre, Curral Grande $-01^{\circ} 57^{\prime} 10.57^{\prime \prime} \mathrm{S} 54^{\circ} 05^{\prime} 22.19^{\prime \prime} \mathrm{W}$ (from city)

45. Muaná, Illha do Marajó, Rio São Miguel, fazenda São Miguel $-01^{\circ} 31^{\prime}$ S $49^{\circ} 29^{\prime} \mathrm{W}$ (from São Miguel village)

46. Óbidos $-01^{\circ} 53^{\prime} 39^{\prime \prime} S 55^{\circ} 32^{\prime} 23^{\prime \prime} \mathrm{W}$ (from city)

47. Óbidos/Oriximiná, Cachoeira da Paciência, Rio Cuminá (= original 'Cachoeira Paciência, Rio') - 00³0'29.90"S 5606'22.57"W (taken from Almeida, 1937)

48. Oriximiná, Cachoeira Porteira, estrada de acesso à Perimetral Norte, alto Rio Trombetas - $01^{\circ} 04^{\prime} 25.5^{\prime \prime} \mathrm{S} 57^{\circ} 01^{\prime} 50.8^{\prime \prime} \mathrm{W}$

49. Oriximiná, Cachoeira Porteira $-01^{\circ} 04^{\prime} 47^{\prime \prime} S 57^{\circ} 02^{\prime} 41^{\prime \prime} \mathrm{W}$

50. Paragominas $-02^{\circ} 58^{\prime} 04.91^{\prime \prime} S 47^{\circ} 22^{\prime} 22.89^{\prime \prime} \mathrm{W}$ (from city)

51. Paragominas, $20 \mathrm{~km} \mathrm{Sul}-03^{\circ} 14^{\prime} 01.44^{\prime \prime} \mathrm{S} 47^{\circ} 17^{\prime} 56.79^{\prime \prime} \mathrm{W}$

52. Paragominas, $25 \mathrm{~km} \mathrm{Sul}-03^{\circ} 14^{\prime} 02.71^{\prime \prime} \mathrm{S} 47^{\circ} 17^{\prime} 11.76^{\prime \prime} \mathrm{W}$

53. Paragominas, Rio Gurupizinho, fazenda Cupuaçu - $03^{\circ} 43^{\prime} 24.00^{\prime \prime} S 47^{\circ} 43^{\prime} 18.15^{\prime \prime} \mathrm{W}$ (in upper Gurupizinho River)

54. Paragominas, Vale S/A, Estrada Mineração - 03 $06^{\prime} 29.06^{\prime \prime} S 47^{\circ} 40^{\prime} 22.98 .00^{\prime \prime} \mathrm{W}$

55. Portel, Rio Aruanã $-03^{\circ} 20^{\prime} 31.1^{\prime \prime}$ 'S 50² $32^{\prime} 49.0^{\prime \prime} \mathrm{W}$ (in original label is “Anapu, Rio Aruanã", but Rio Aruanã, a river [Aruanã] and also a village [Rio Aruanã], are located in upper Pacajás River and not cross the Anapu municipality, being Portel the largest administrative unit along this river and where is Rio Aruanã village)

56. Santa Bárbara do Pará, PA 391, Ramal do Araci, km $4-01^{\circ} 12^{\prime} 50.03^{\prime \prime}$ S $48^{\circ} 17^{\prime} 41.37^{\prime \prime} \mathrm{W}$

57. Santarém, (Rio) Arapiuns, Aningalzinho, Resex Tapajós-Arapiuns - $02^{\circ} 35^{\prime} 28.13^{\prime \prime} S 55^{\circ} 23^{\prime} 41.19^{\prime \prime} \mathrm{W}$

58. Santarém, Curuá-Una, 44 km S e 40 km E de Santarém - 02 $48^{\prime} 26.6^{\prime \prime} S 54^{\circ} 19^{\prime} 24.4^{\prime \prime} \mathrm{W}$

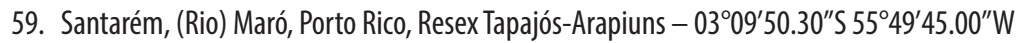

60. Santarém, Rio Ituqui ('Rio Ituquy') - 02³4'31.70"S $54^{\circ} 21^{\prime} 51.07^{\prime \prime} \mathrm{W}$ (from Santarém, Taperinha locality)

61. Santarém, Taperinha (all specimens bring together by German naturalist Godofredo Hagmann) - $02^{\circ} 34^{\prime} 31.70^{\prime \prime} S 54^{\circ} 21^{\prime} 51.07^{\prime \prime} \mathrm{W}$

62. Santarém, (Rio) Tapajós, Escrivão, Resex Tapajós-Arapiuns - $03^{\circ} 26^{\prime} 22.13^{\prime \prime} S 55^{\circ} 21^{\prime} 31.61^{\prime \prime} \mathrm{W}$

63. Santarém, Rio Tapará-miry - $02^{\circ} 23^{\prime} 32.00^{\prime \prime} S 54^{\circ} 33^{\prime} 11.63^{\prime \prime} \mathrm{W}$

64. São João (= São João do Araguaia), Rio Araguaia, - 0947'37.6"S 50¹5'33.5"W (from village)

65. Terra Santa $-02^{\circ} 05^{\prime} 07.23^{\prime \prime} S 56^{\circ} 29^{\prime} 08.05^{\prime \prime} \mathrm{W}$ (from city)

66. "Trairão or Uruará" (Elildo Carvalho Jr. in pers. comm.), Iriri, "Frei" - Imprecise locality, since Rio lriri is at least 195 km southeastern far away of Santarém municipality. - without coordinates

67. Tucuruí, Rio Tocantins, margem esquerda - $04^{\circ} 02^{\prime} 33.1^{\prime \prime} S 49^{\circ} 46^{\prime} 14.6^{\prime \prime} \mathrm{W}$

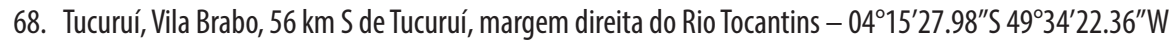

\section{Rio Grande do Sul:}

69. Arambaré/Camaquã divisa (= 'Camaquã, Arambaré' in specimen label) $-30^{\circ} 50^{\prime} 53.8^{\prime \prime} 551^{\circ} 46^{\prime} 45.9^{\prime \prime} \mathrm{W}$

70. Cachoeira do Sul, BR $290-30^{\circ} 15^{\prime} 31^{\prime \prime} S 52^{\circ} 51^{\prime} 22^{\prime \prime} \mathrm{W}$

71. Fontoura Xavier - $28^{\circ} 58^{\prime} 48.79^{\prime \prime} S 52^{\circ} 21^{\prime} 08.79^{\prime \prime} \mathrm{W}$ (from city)

72. Rio Grande, Vila Mirim - $33^{\circ} 04^{\prime} 19.64^{\prime \prime} S 53^{\circ} 12^{\prime} 02.62^{\prime \prime} \mathrm{W}$

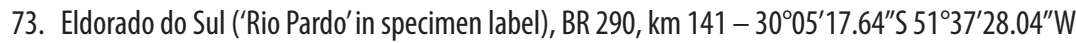

74. São Jerônimo, Conde $-29^{\circ} 58^{\prime} 11.29^{\prime \prime} S 51^{\circ} 47^{\prime} 50.15^{\prime \prime} \mathrm{W}$ (from village)

\section{Rondônia:}

75. Costa Marques, BR $429-12^{\circ} 26^{\prime} 09.27^{\prime \prime} S 64^{\circ} 13^{\prime} 43.56^{\prime \prime} \mathrm{W}$

\section{Roraima:}

76. Mucajaí, T.F. do Rio Branco, baixo Rio Mucajaí - 02²8'03.9”N 60³'16.9”W

\section{Tocantins:}

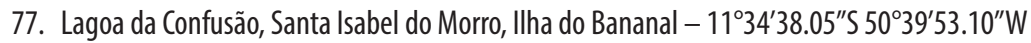

78. Rio Araguaia - $11^{\circ} 41^{\prime} 22.34^{\prime \prime} \mathrm{S} 50^{\circ} 46^{\prime} 16.87^{\prime \prime} \mathrm{W}$ (from middle river) 


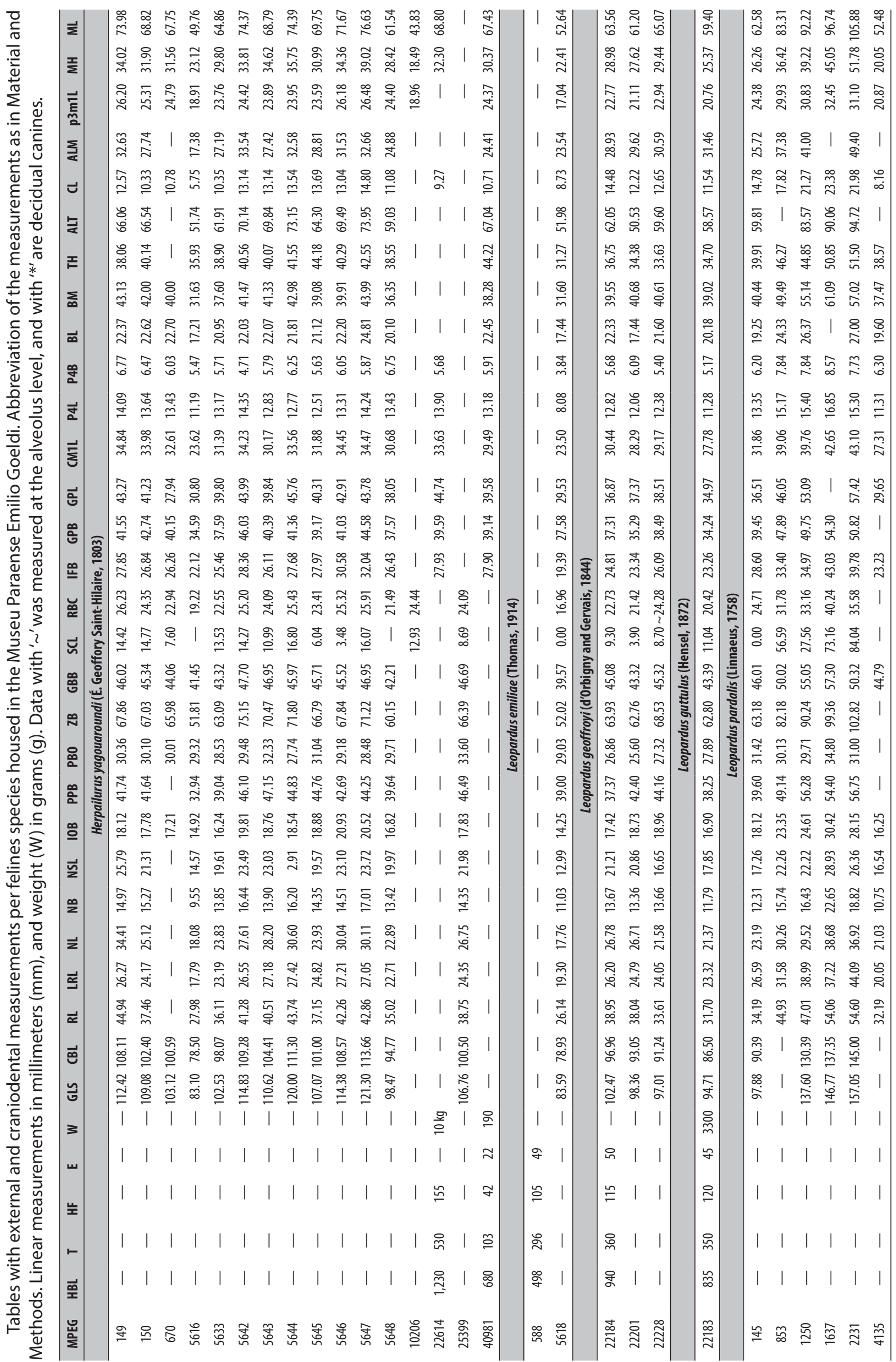


| $\mid$ |

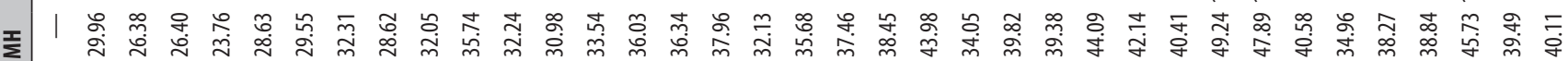

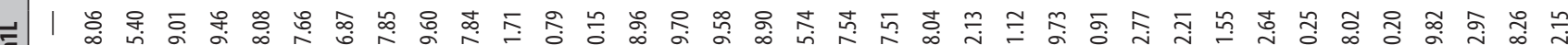
हᄐ 隹

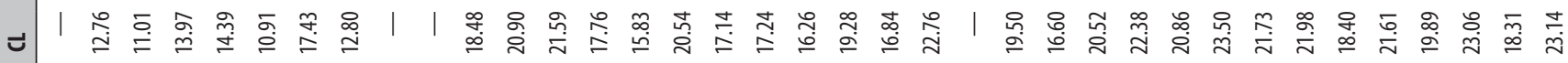

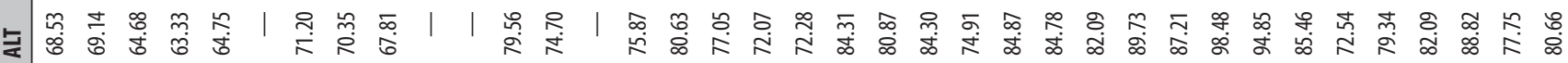

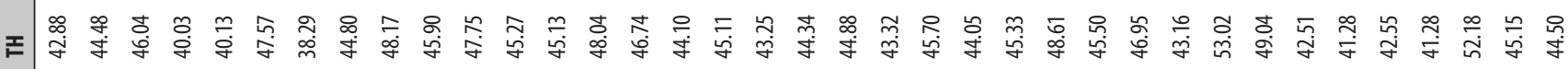

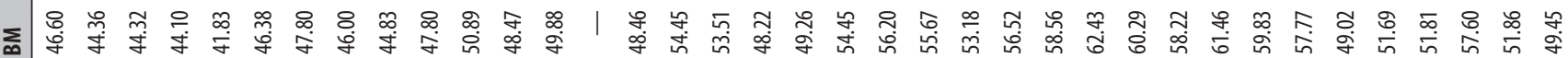
ఐ

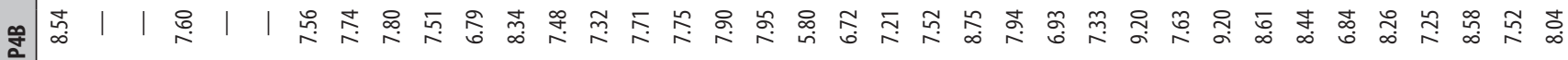

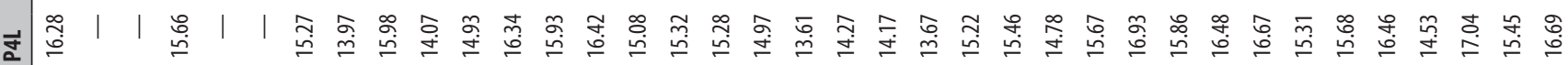

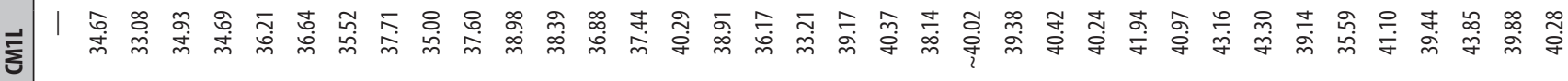
군

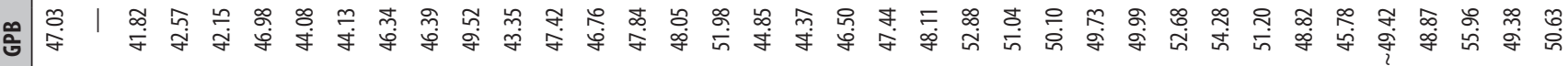

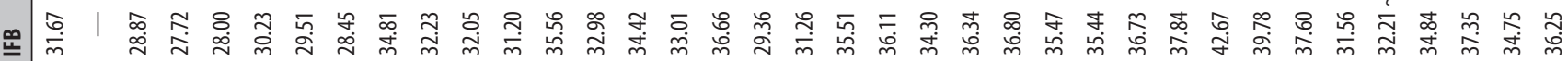
所

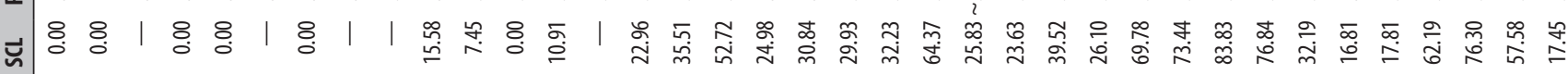

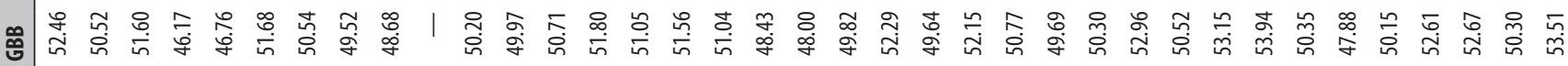

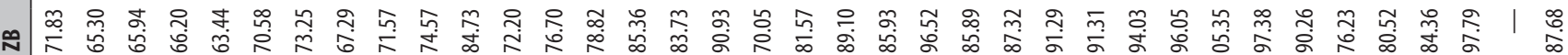

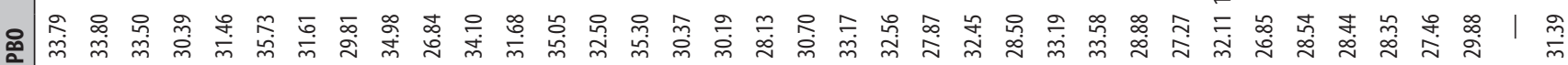

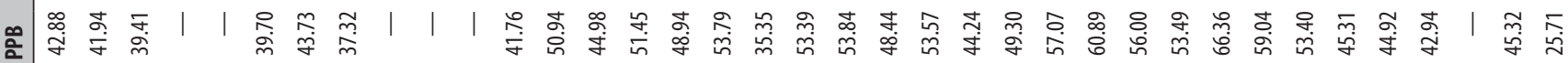

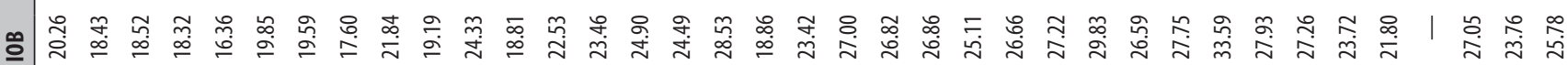

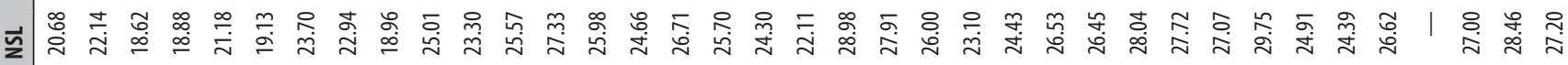

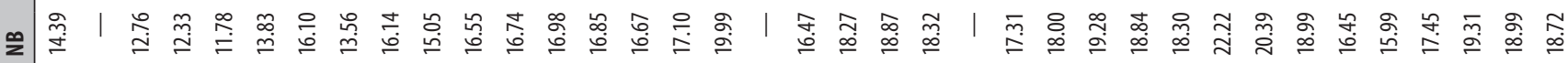

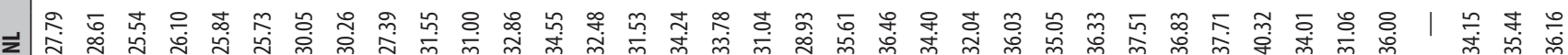
뚜

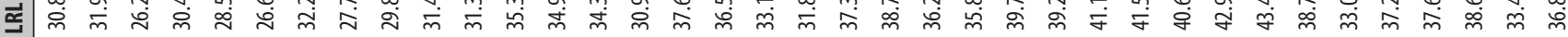

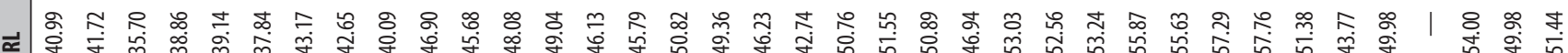
శ్

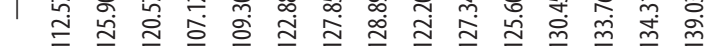
บ 운 जo 


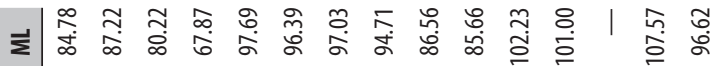

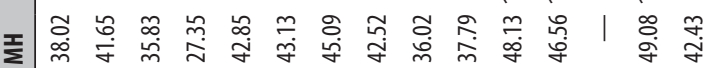

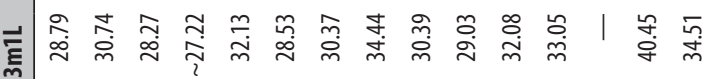

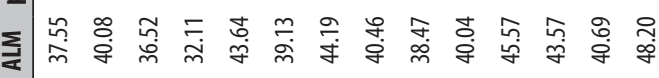

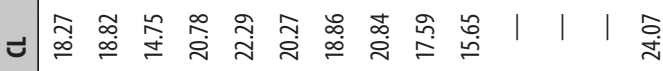

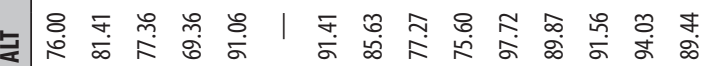

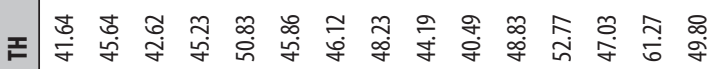

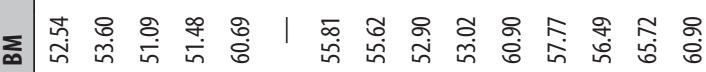

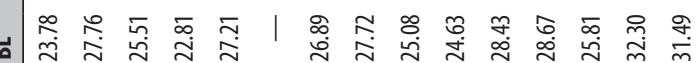

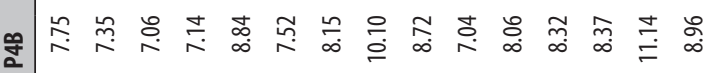

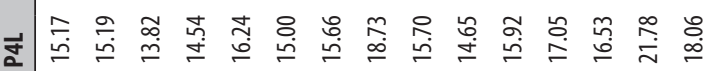

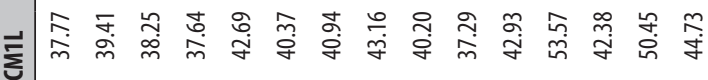

ప ॥

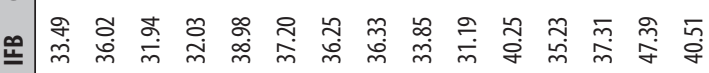

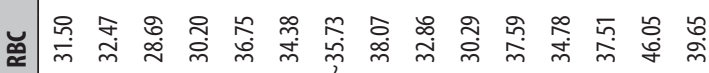
己ు

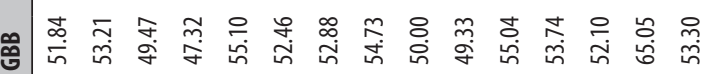

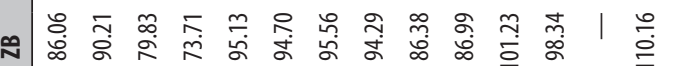

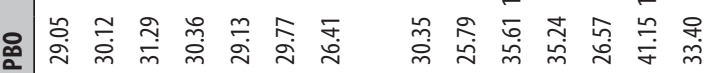

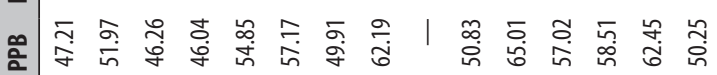

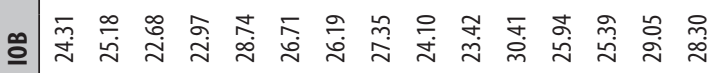

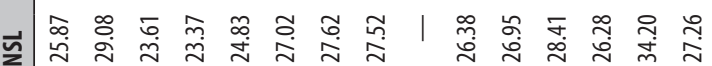

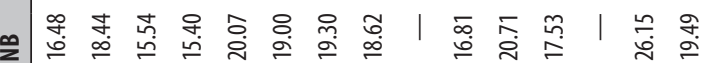

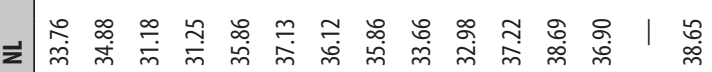

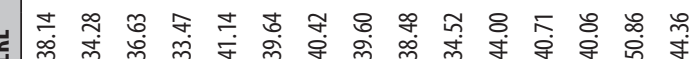
g.

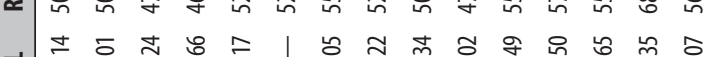

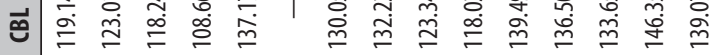

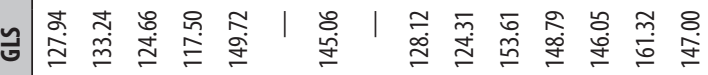

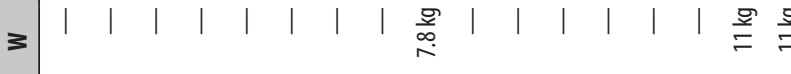

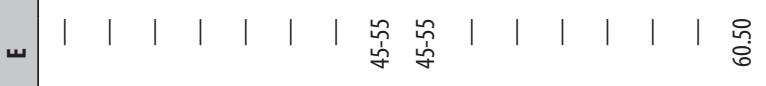

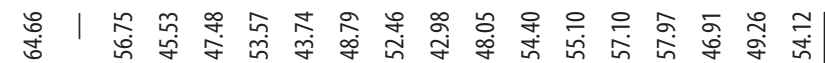
|

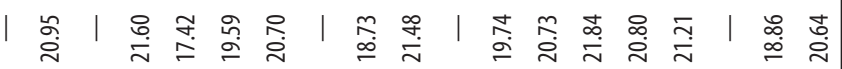
芯 | 吕 | 守

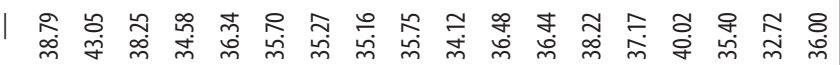
|

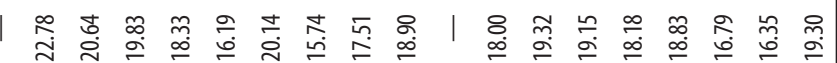

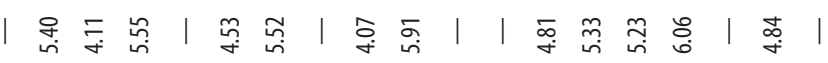

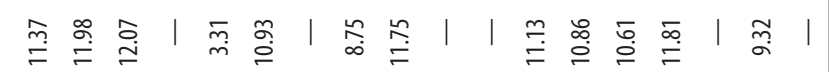

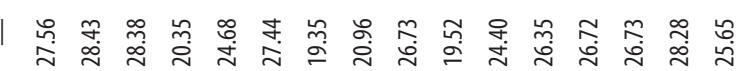

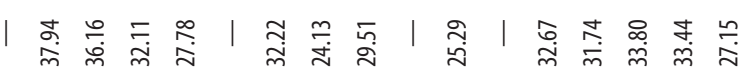

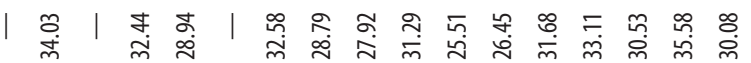

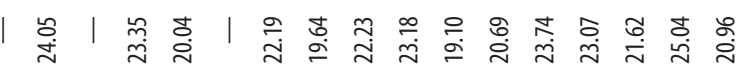

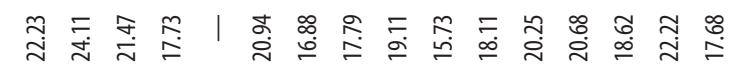
융

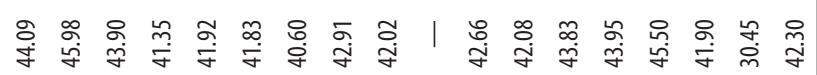

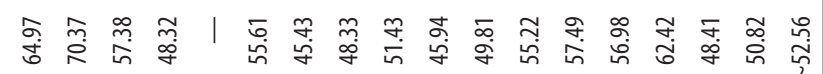

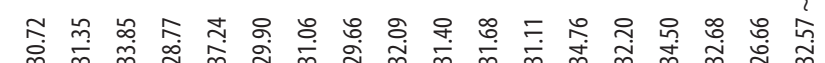

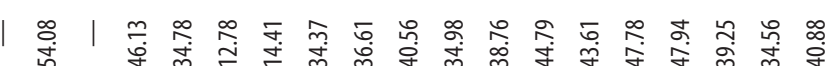

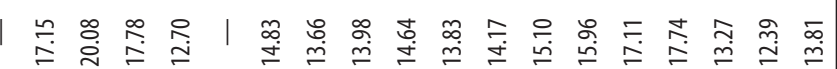

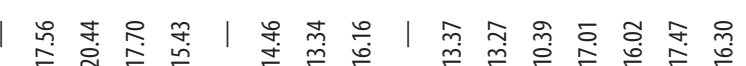

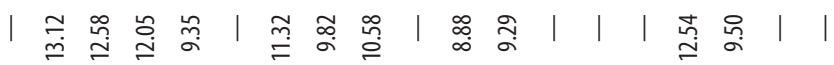

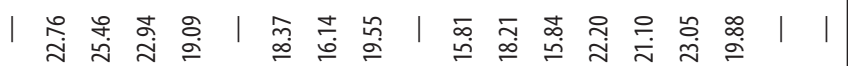

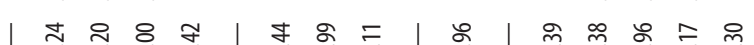

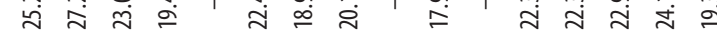

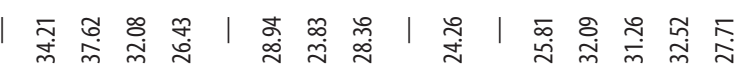

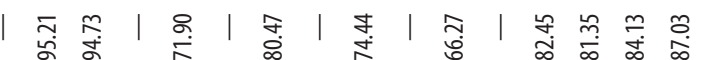

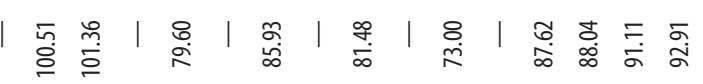

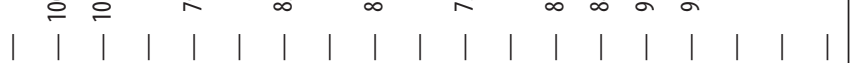

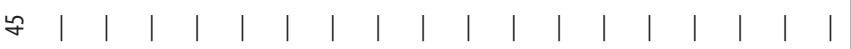

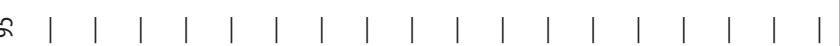
! | | | | | | | | | | | | | | | |

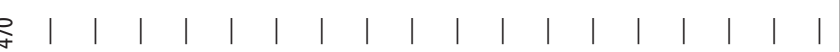

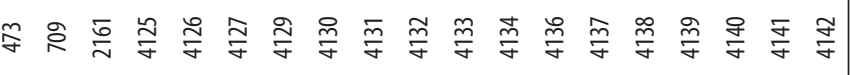




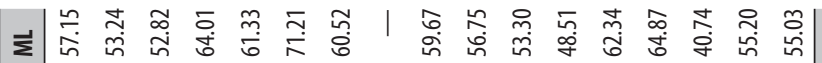

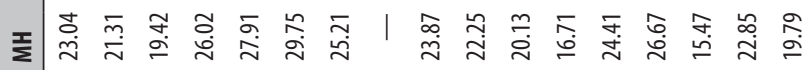

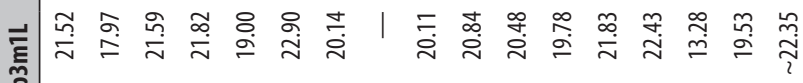
$\sum$ 员

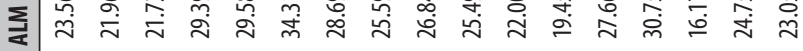

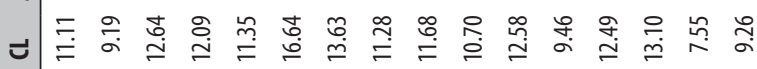

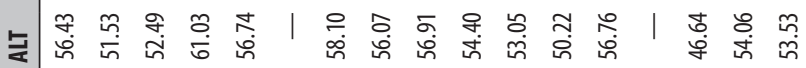

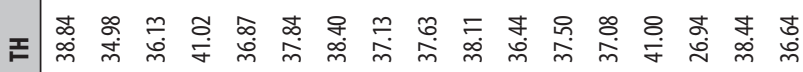

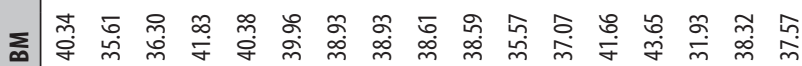

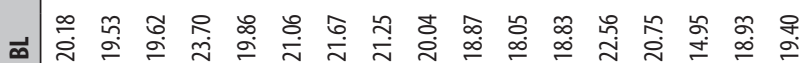

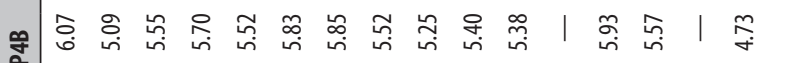

|윰

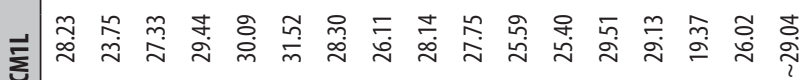

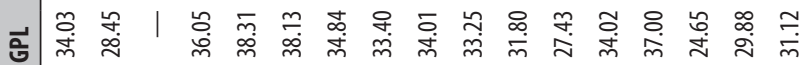

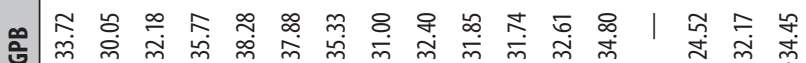

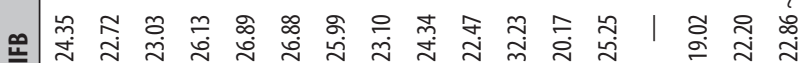

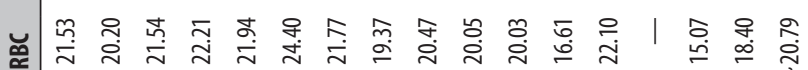
பㅆ

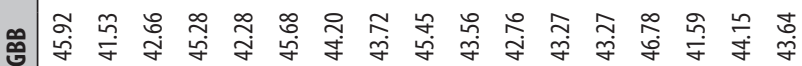

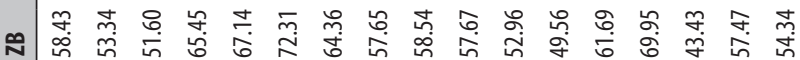
ஜ

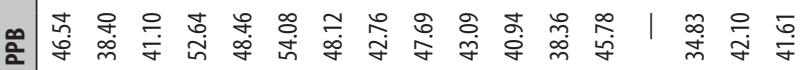

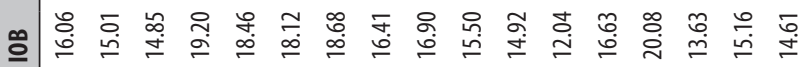

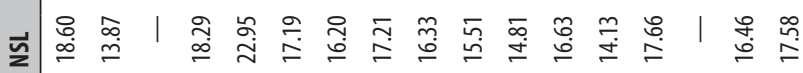

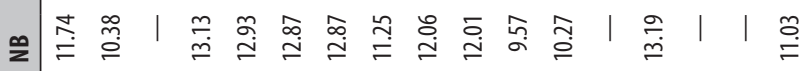

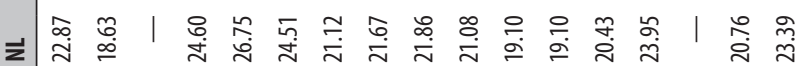

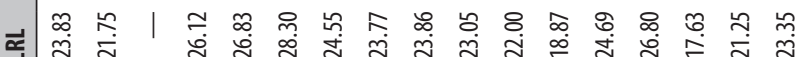

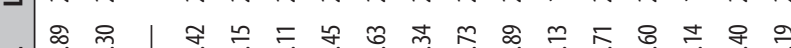

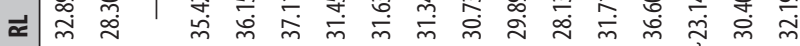
म艹 萬芯

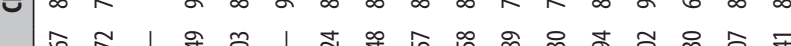
บ $\begin{array}{lllllllllllllllllll} & 3 & \mid & \mid & \mid & \mid & \mid & \mid & \mid & \mid & \mid & \mid & \mid & \mid & \mid & 0 & \frac{8}{\infty}\end{array}$

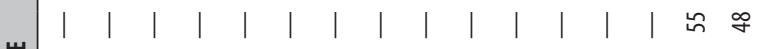
| $\mid$ | | | | | | | | | | | | | | | | o 荘 $\vdash$ 뽀

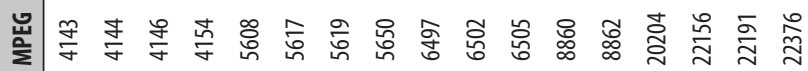

守

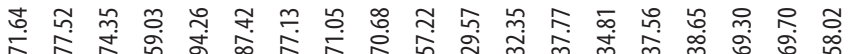
于. โ

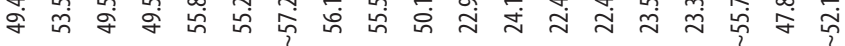
๙ 趈

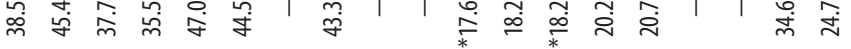

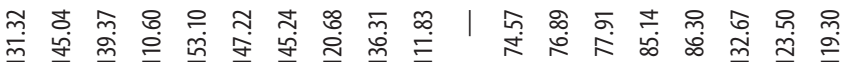

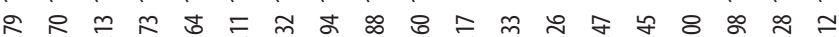
ổ

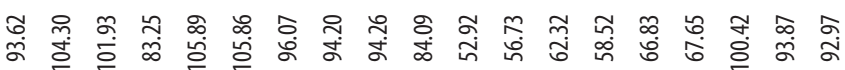

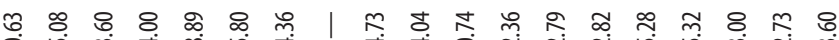

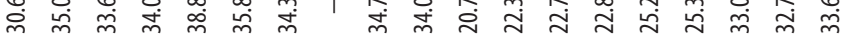
茫芯命 궁 웅

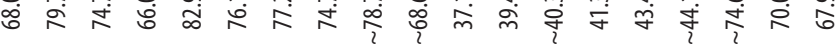

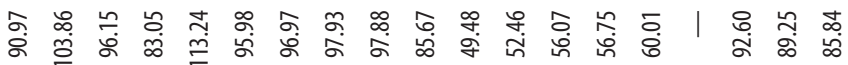

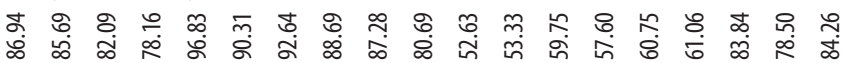
志 员 年 桁

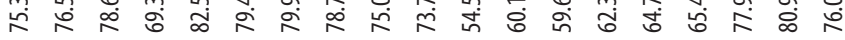

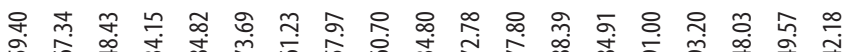

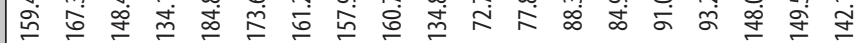
亲字字 柯

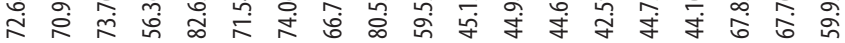

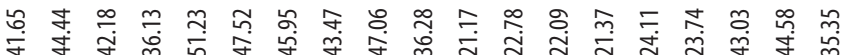

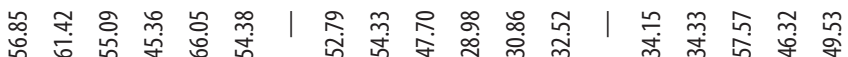

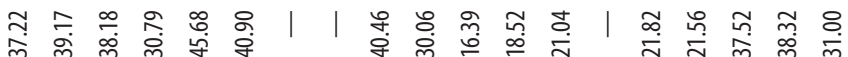

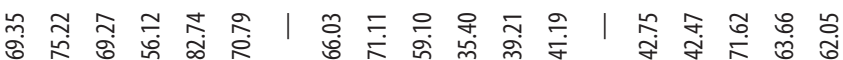

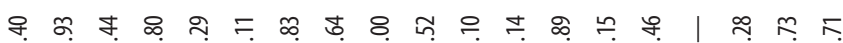

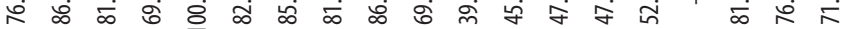
下 ু

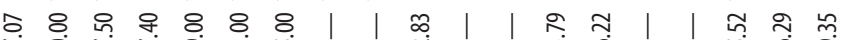

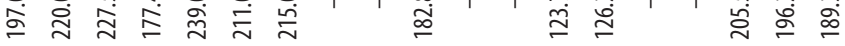
8 \& \& \& \& \& \& 8 \%

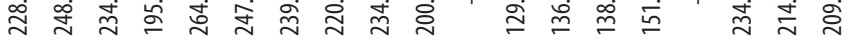

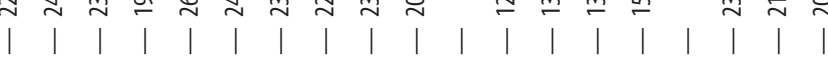

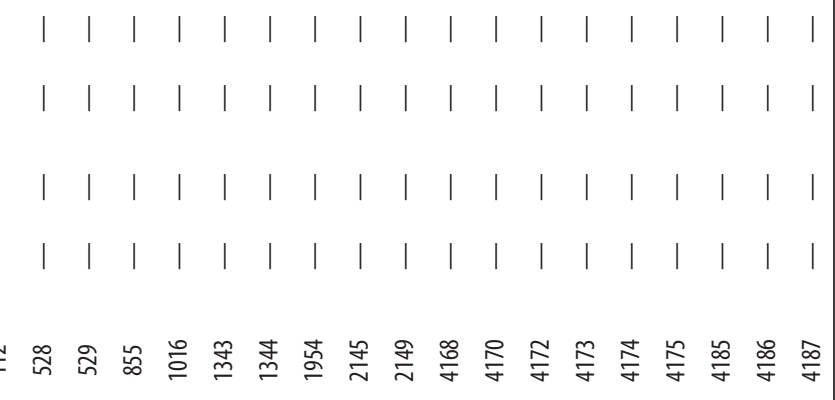




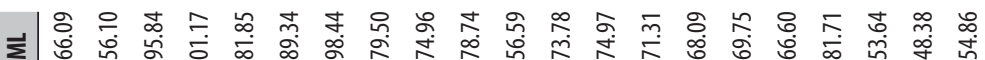

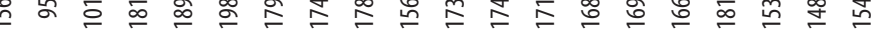

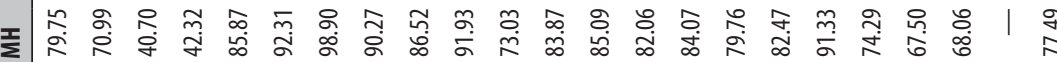

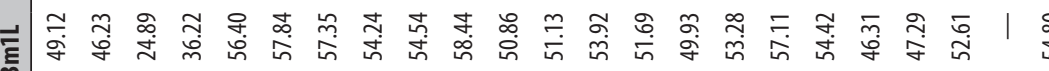

స్

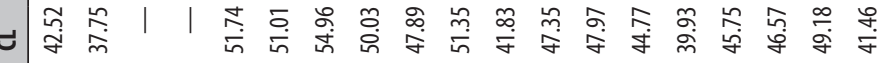

灵芯

I

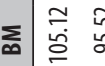

•

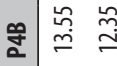

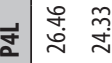

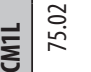

는 훙

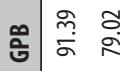

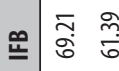

莍

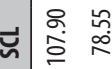

뿡 占

贻

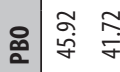

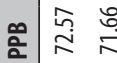

으 辛

जు $\begin{array}{cc}\infty & \infty \\ \dddot{F} & \stackrel{\pi}{q}\end{array}$

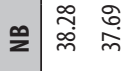

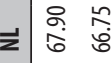

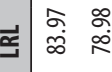

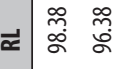

•

บ

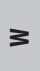

3

㟔

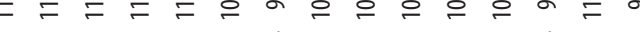

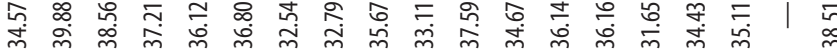
бु $m$ \%े స్ల

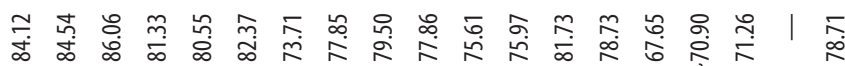

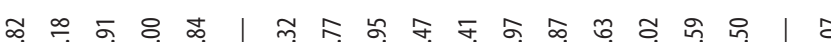
守 œ 章

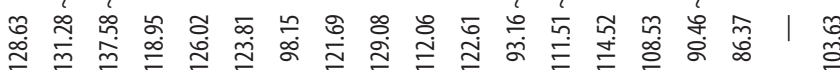

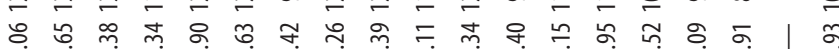

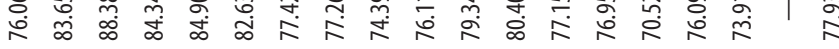

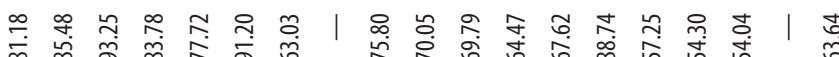

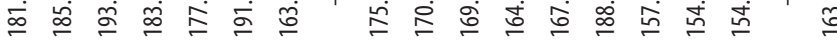
స ה్

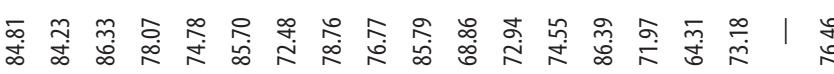

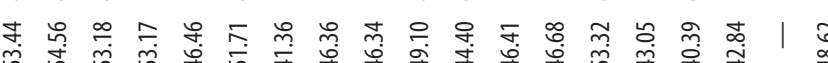
लं

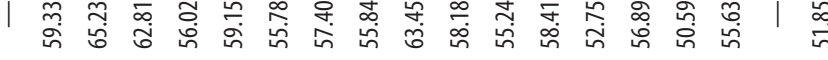

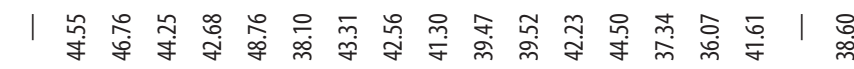

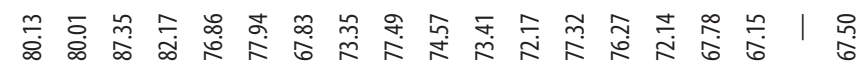
F

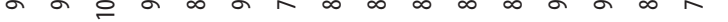
$\therefore=$

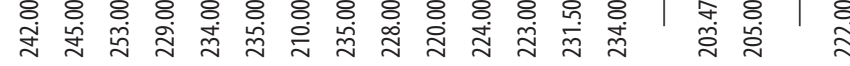

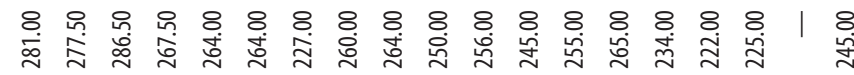

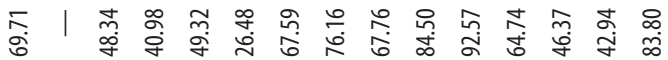
m 守 守

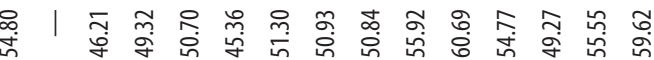

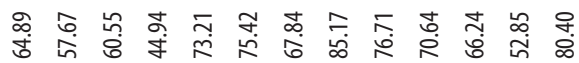

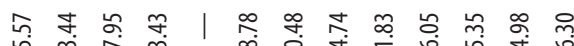

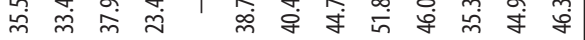

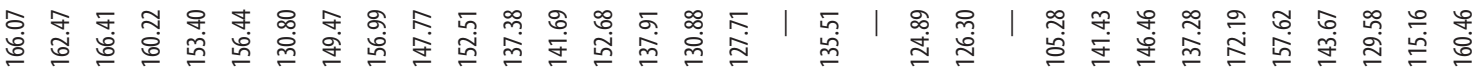

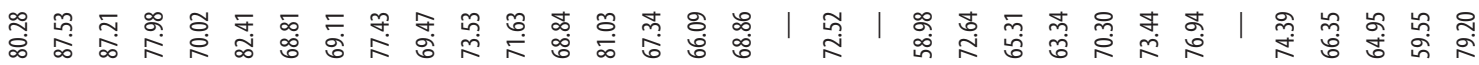

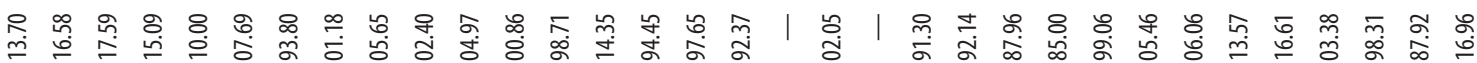

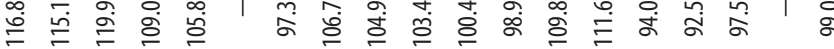

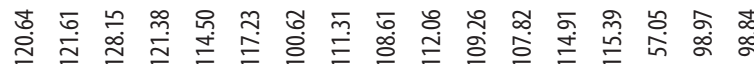
$\mid$ 旁

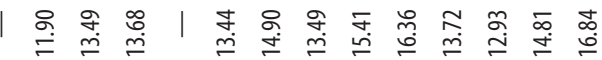

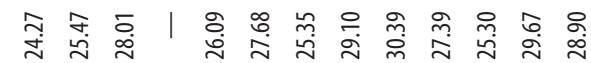

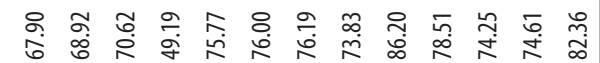

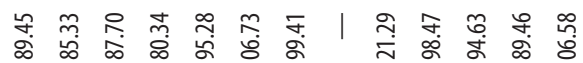
๖ 官合芯

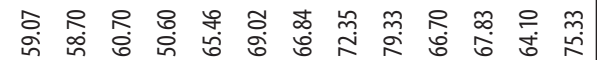

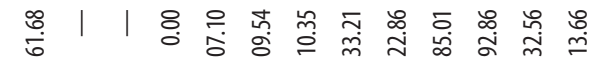
t

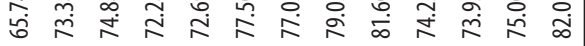
ঢై

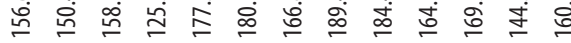
茫亲

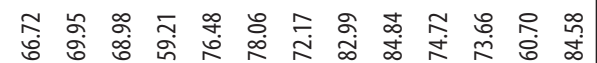

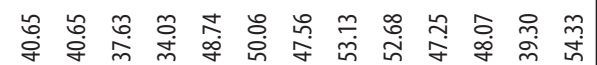

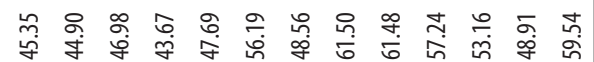

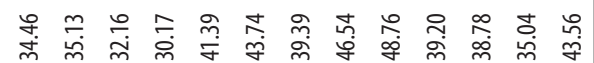

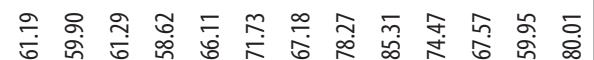
必

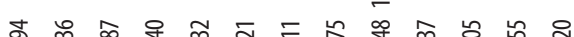

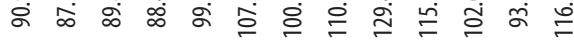
। 少 | 8 8 8 8 8 8 8 8 8 \% 8 옹 


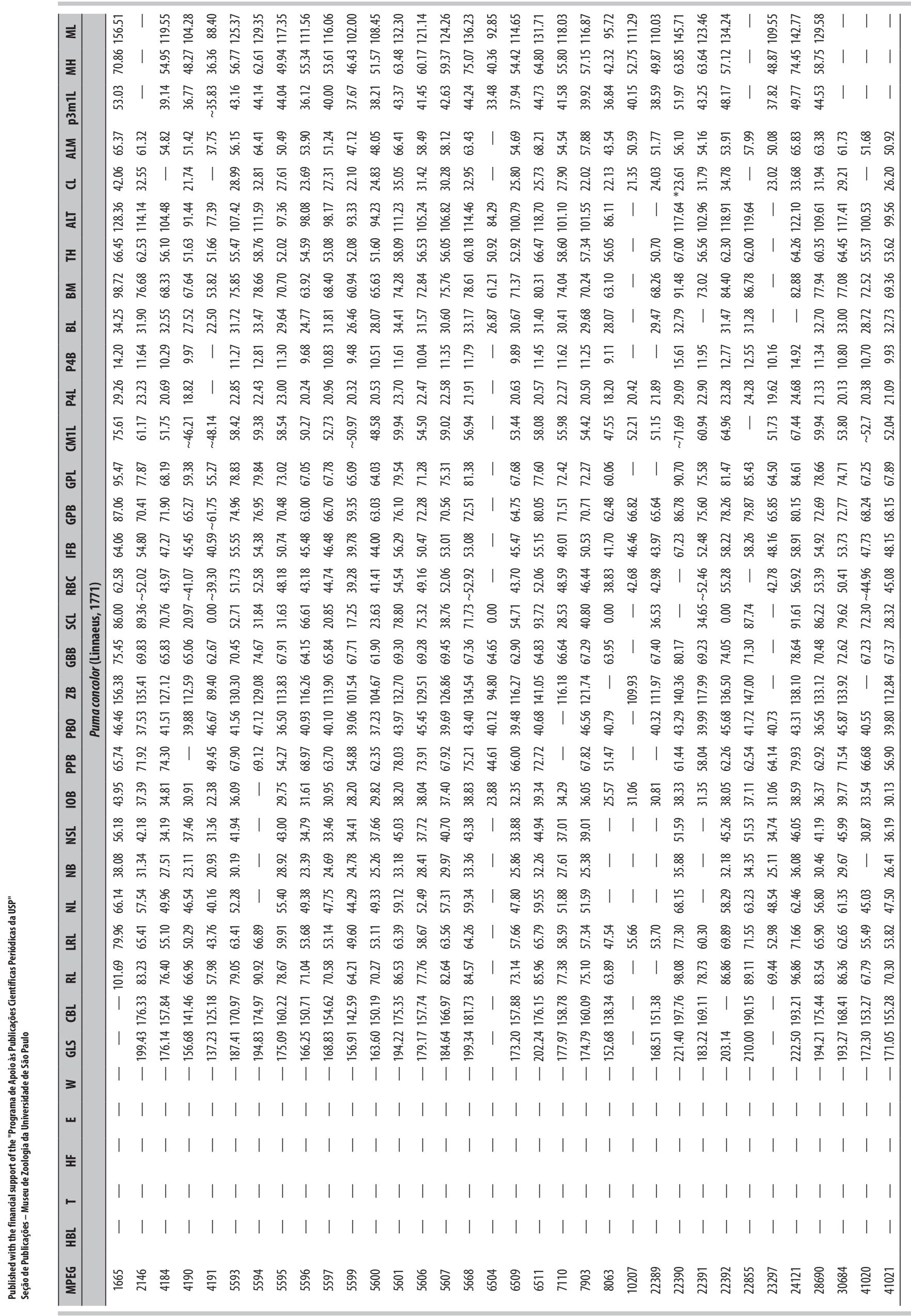

